Canadian Science Publishing

Applied Physiology, Nutrition, and Metabolism Physiologie appliquée, nutrition et métabolisme

\title{
Thermal stress, human performance and physical employment standards
}

\begin{tabular}{|c|c|}
\hline Journal: & Applied Physiology, Nutrition, and Metabolism \\
\hline Manuscript ID & apnm-2015-0518.R1 \\
\hline Manuscript Type: & Review \\
\hline Date Submitted by the Author: & 18-Dec-2015 \\
\hline Complete List of Authors: & $\begin{array}{l}\text { Cheung, Stephen; Brock University, Department of Kinesiology } \\
\text { Lee, Jason KW; DSO National Laboratories, Defence Medical \& } \\
\text { Environmental Research Institute; National University of Singapore, Yong } \\
\text { Loo Lin School of Medicine; Nanyang Technological University, Lee Kong } \\
\text { Chian School of Medicine } \\
\text { Oksa, Juha; Finnish Institute of Occupational Health, Oulu, }\end{array}$ \\
\hline Keyword: & heat stress, cold stress, occupational physiology, testing, work \\
\hline
\end{tabular}

SCHOLARONE

Manuscripts 


\section{Thermal stress, human performance and physical employment standards}

Stephen S. Cheung, Ph.D. ${ }^{1}$; Jason K.W. Lee, Ph.D. ${ }^{2,3,4}$; Juha Oksa, Ph.D. ${ }^{5}$

${ }^{1}$ Environmental Ergonomics Laboratory, Department of Kinesiology, Brock University, St.

Catharines, Canada

${ }^{2}$ Defence Medical and Environmental Research Institute, DSO National Laboratories, Singapore

${ }^{3}$ Yong Loo Lin School of Medicine, National University of Singapore, Singapore

${ }^{4}$ Lee Kong Chian School of Medicine, Nanyang Technological University, Singapore

${ }^{5}$ Finnish Institute of Occupational Health, Physical Work Capacity team, Oulu, Finland

Running Head: Thermal stress and physical employment standards

\section{Correspondence:}

Stephen S. Cheung, Ph.D.

Department of Kinesiology

Brock University

1812 Sir Isaac Brock Way

St. Catharines, ON, L2S-3A1

CANADA

Email: scheung@brocku.ca

Tel.: +1-905-688-5550x5662 


\begin{abstract}
Many physically demanding occupations in both developed and developing economies involve exposure to extreme thermal environments that can affect work capacity and ultimately health. Thermal extremes may be present in either an outdoor or an indoor work environment, and can be due to a combination of the natural or artificial ambient environment, the rate of metabolic heat generation from physical work, processes specific to the workplace (e.g., steel manufacturing), or through the requirement for protective clothing impairing heat dissipation. Together, thermal exposure can elicit acute impairment of work capacity and also chronic effects on health, greatly contributing to worker health risk and reduced productivity. Surprisingly, in most occupations even in developed economies, there are frequently no standardized or enforced heat or cold safety standards for workers. Furthermore, specific physical employment standards or accommodations for thermal stressors are rare, with workers commonly tested under nearperfect conditions. This review surveys the major occupational impact of thermal extremes and existing employment standards, proposing guidelines for improvement and areas for future research.
\end{abstract}

Keywords: Heat stress; cold stress; occupational physiology; testing; work 


\section{Abbreviations}

EMG. Electromyography.

$\mathrm{HR}_{\max }$. Maximum heart rate.

HRR. Heart rate reserve.

MEMG. Maximal electromyographic activity.

\%MEMG. Percentage maximal electromyographic activity

NIOSH. National Institute for Occupational Safety and Health

OSHA. Occupational Safety and Health Administration

$\mathrm{T}_{\text {core. }}$ Core body temperature.

$\dot{\mathrm{V}} \mathrm{O}_{2 \max }$. Maximal oxygen uptake.

$\% \mathrm{VO}_{2 \max }$. Percentage maximal oxygen uptake

WBGT. Wet-bulb globe temperature. 


\section{Introduction}

Challenging occupational tasks are often performed in environmentally stressful situations, such as those involving high or low ambient temperatures. High temperatures and heat stress can arise due to a combination of the ambient environment (e.g., outdoor agricultural work during summer, ultra-deep mining), metabolic heat production from physical work (e.g., construction, wildland firefighting), and also the insulation from protective clothing (e.g., urban firefighting and hazardous waste disposal). At the same time, due to a combination of low temperatures, passive work, or inadequate clothing, cold stress can occur in many resource industries (e.g., fishing, petroleum extraction) and in all-season occupations such as construction and in the military. Heat and cold stress can also occur in both outdoor occupations and also indoor settings, such as manufacturing and food processing, and in work with minimal physical activity.

Using a combination of behavioural and physiological responses, humans are able to maintain a reasonably constant core body temperature $\left(\mathrm{T}_{\text {core }}\right)$ of $37 \pm 1{ }^{\circ} \mathrm{C}$ throughout their lives despite a wide range of ambient temperatures, with generally efficient thermoregulation occurring throughout a $\mathrm{T}_{\text {core }}$ range of 35 to $40^{\circ} \mathrm{C}$ (Parsons 1993). When this balance is disturbed, thermal stress presents a multitude of potential issues that may reduce operational capacity or increase acute and chronic health risks for the worker. From a purely physical perspective, Galloway and Maughan (1997) demonstrated an 'inverted-U' relationship between ambient temperature and submaximal exercise tolerance time, with a peak at $10.5^{\circ} \mathrm{C}$ and equivalent decreases at $3.6^{\circ} \mathrm{C}$ and $20.6^{\circ} \mathrm{C}$, with a further impairment at $30.5^{\circ} \mathrm{C}$. Exercise in the heat also can increase the risk for the onset of exertional heat illness (Armstrong et al. 2007). Thus, thermal stress can directly alter operational capacity, both by decreasing work tolerance and also by requiring changes to work scheduling such as increased rest and recovery periods. Cold stress can rapidly reduce manual dexterity (Heus et al. 1995, Cheung et al. 2003), increase the work 
involved in balance and maintaining posture (Makinen et al. 2005), and increase neuromuscular strain from a given task (Sormunen et. al. 2009), reducing the total work capacity and increasing the risk for chronic issues such as repetitive strain injuries. Furthermore, cognitive functioning, decision making, and task performance may be impaired by both heat and cold stress (Pilcher et al. 2002, Hancock et al. 2007), and this can increase the risk of accidents in the workplace.

Several approaches can be taken to adapt the workplace to minimize the impact from thermal stress. A common method has been to develop environmental exposure guidelines that maintain workers within a safe or manageable zone of physical and mental tolerance. However, one limitation is that such guidelines are designed to be conservative in protecting the majority of individuals, such that operational tolerance may be arbitrarily reduced for the majority of workers. Another approach is to select workers specifically for particular occupations based on their individual characteristics, or alternately creating employment standards based on known responses to thermal stress. Both approaches require a detailed understanding of how thermal stress affects both physiology and behaviour. This review surveys the major occupational impact of thermal extremes on occupational performance health, and safety, along with examples of existing employment standards and proposal of guidelines for improvement and areas for future research.

\section{Heat stress}

As work is performed throughout all regions of the world, environmental conditions faced by workers can vary widely both geographically and seasonally. In many equatorial regions, temperatures can remain high throughout the year, regularly averaging $>30^{\circ} \mathrm{C}$ through the year and spiking to $>50^{\circ} \mathrm{C}$. In temperate regions, very cold winters may alternate with hot summers, creating special challenges during the period of heat adaptation. Physiologically, the initial 
response to heat stress is increased conductive and convective heat transfer from the body's core to the periphery. This is achieved through increased flow of blood to the extremities and vasodilation of skin blood vessels, permitting heat transfer to the environment (Johnson et al. 2014). The cutaneous circulation receives a high level of blood flow per unit volume, with maximal flows being estimated to be in the region of $275 \mathrm{ml} \cdot 100 \mathrm{ml}$ tissue ${ }^{-1} \cdot \mathrm{min}^{-1}$ and absolute levels reaching in excess of $8 \mathrm{~L} \cdot \mathrm{min}^{-1}$ (Rowell 1993). With greater heat dissipation demands and where the thermal gradient between the body and environment is small, sweating becomes the dominant method of heat dissipation. The production and evaporation of sweat from the skin surface represents a highly efficient mode of heat dissipation to the environment, with full evaporation of $1 \mathrm{~L}$ of sweat transferring approximately $2,400 \mathrm{~kJ}$ of heat energy to the environment.

With climate change has come increasing awareness of the health risks stemming from warmer temperatures and acute regional heat events in the general population. Comparisons of heat-related illness patterns across multiple cities and countries in northeast Asia (Chung et al. 2015) and internationally (Guo et al. 2014) reported that, despite spatial heterogeneity in frequency, hot temperature was strongly associated with an increase in cardiovascular mortality within a short time lag of 1-3 days. Specific epidemiological reports on regional heat waves such as in Chicago 1995 (Semenza et al. 1996), France 2003 (Fouillet et al. 2006) and China (Bai et al. 2014), all support this direct association between ambient temperature during acute heat waves and increased mortality. In the United States, an estimated $31 \%$ of 2,000 weather-related deaths per year between 2006 and 2010 were attributed to heat exposure (Berko et al. 2014), and future increases are expected due to a combination of higher global temperatures, more severe weather events (Huang et al. 2011), and increasing urbanization (Gabriel and Endlicher 2011). The 
impact of temperature fluctuations on morbidity is less clear, with a recent epidemiological metaanalysis reporting a $3.2 \%$ increase in respiratory morbidity with $1{ }^{\circ} \mathrm{C}$ increase on hot days, but no association with cardiovascular morbidity (Turner et al. 2012).

\section{Health and occupational impact}

Concurrently, hyperthermia - a sustained rise in body temperature - and exertional heat illnesses arising from work in hot environments are becoming recognized as a major occupational health issue in both developed and developing economies (Lucas et al. 2014). In the United States, the Occupational Safety and Health Act of 1970 regulates the protection of workers from undue harm, but the Occupational Safety and Health Administration (OSHA) does not have a federally standardized or enforced heat standard. Nevertheless, 20 cases of heat illness - including 13 deaths - were federally cited in 2012-13 by OSHA for not providing a place of employment free of recognized hazards (Arbury et al. 2014). In the most populous Canadian province of Ontario, 785 heat illness events were identified in 2004-2010 from emergency department records (1.7 per 1,000,000 full-time equivalent months), with a further 612 events derived from lost time claim records (Fortune et al. 2013). Of these work-related incidents, a significant $75 \%$ increase in emergency visits occurred for each degree beyond $22^{\circ} \mathrm{C}$ in ambient maximum temperature (Figure 1) (Fortune et al. 2014).

\section{Insert Figure 1 about here (Fortune 2014).}

Heat stress in the workplace may come about due to several contributing factors occurring in isolation or in combination:

- High ambient temperatures coupled with high humidity, which can occur in both outdoor and indoor settings. Indoor heat exposure may be endemic in particular environments due to situational requirements, such as operating theatres being kept 
at high ambient temperatures (e.g., $26^{\circ} \mathrm{C}$ ) with the purported aim of preventing intraoperative patient hypothermia. Indoor heat exposure can also come about due to high heat-producing processes within the workplace (e.g., manufacturing, commercial food preparation). Indoor heat exposure can also exist during heat waves (Quinn et al. 2014), exposing individuals who may not normally experience high working temperatures or be acclimatized, or else providing minimal opportunity for recovery between work shifts.

- Intense or prolonged work generating high metabolic heat production. A challenge to thermal equilibrium in the heat is not just the stress imposed by the external environment but also the extreme variations in metabolic heat generation, as $>70-80 \%$ of metabolic energy is converted to heat in the course of mechanical movement. This heat production can range from 70 to $100 \mathrm{~W}$ in resting adults, 280 to $350 \mathrm{~W}$ at mild walking pace, to $>1000 \mathrm{~W}$ during heavy exercise (Parsons 1993). Even relatively stationary work can elicit very high heat production due to sustained isometric or other resistance exercise; heat production in astronauts during extravehicular activities can regularly exceed $600 \mathrm{~W}$ and can, in extreme cases, rise above $1000 \mathrm{~W}$ (Cowell et al. 2002).

- The frequent use of protective clothing, such as the military, firefighting, and hazardous waste disposal, may also cause additional heat stress via the impairment of heat dissipation and sweat evaporation through the clothing ensemble (McLellan et al. 2013). 
In addition to the main environmental or occupational-specific factors discussed above, individual characteristics can vary greatly amongst workers, further contributing to variability in response to heat stress and risk of heat related illnesses.

\section{Future projections}

With climate warming, the impact of heat waves on general population morbidity and mortality risks has been extensively reported in temperate and tropical climates, and in both urban and rural regions. (Bai et al. 2014; Berko et al. 2014; Chung et al. 2015; Kjellstrom and Weaver 2009; Yip et al. 2008). Projections of climate change over the coming century suggest increasing incidences of heat-related mortality in both the general public and in occupational settings (Gubernot et al. 2014; Jay and Kenny 2010; Kjellstrom et al. 2013; Lundgren et al. 2013; Xiang et al. 2014). Epidemiological studies also suggest that the highest risk of excessive heat exposure are in tropical and lower to middle income countries, possibly attributable to a large informal work sector, location in a hot environment, and dense populations (Lucas et al. 2014).

Climate change will lead to a reduced productivity in accordance to work exposure limits while increasing economic demands (Kjellstrom et al. 2009; Schulte and Chun 2009). In four hot summer regions spread around the world, mapping of temperature patterns revealed a $0.5-1^{\circ} \mathrm{C}$ increase in wet bulb globe temperature outdoors in the shade or indoors without cooling between 1975 and 2000 (Hyatt et al. 2010). From 1982 - 2012, the number of days when WBGTmax (indoors) exceeded $29^{\circ} \mathrm{C}$ in Singapore have increased from $\sim 10$ to $\sim 70$ annually, for a linear trend of 20.8 more days per decade, and work productivity at moderate $(300 \mathrm{~W})$ and heavy $(400$ W) at this temperature is estimated to decrease by 9 and 25\%, respectively (Kjellstrom et al. 2013). Such warming trends will rapidly increase the size of the regions and length of time where increased occupational heat exposure risks will occur, to the point of limiting available 
work time. In the coming years, climate change may also converge with the changing trends in workforce demographics, notably the increasing access for women to traditionally maledominated occupations (e.g., military and first responder) along with the increasingly aging workforce (e.g., mining). Increased mechanization of work, along with societal trends for increased sedentary behaviour, may decrease physical fitness and increase body fatness - two prime predictors for impaired heat tolerance (Selkirk and McLellan 2001). Specific reviews on physical employment standards as they may impact women and older workers are detailed in accompanying reviews, but these trends highlight the need for further research into the effects of thermal stress on specific populations with potentially different responses.

\section{Heat mitigation strategies}

As hazards of occupational heat exposure increase due to global warming, it is important for employers to implement effective heat mitigation strategies in the workplace to reduce such risks and ensure a healthy and safe working environment. Heat mitigation strategies that are currently used in occupational settings include heat acclimatization, hydration regimes, work-rest cycles and active cooling.

Heat acclimatization refers to the physiological changes (e.g. lower heart rate and lower core temperature) following consecutive days of physical exertion in hot environments, resulting in an enhanced tolerance to heat stress (Taylor 2011; Nielsen 1998; Armstrong and Maresh 1991). Several militaries (US, UK, Australia, and Singapore) have developed heat acclimatization regimes prior to deployment (TBMED507, 2013; MOD, 2012; Taylor et al., 1997; Lee et al. 2012). Generally, these protocols recommend 14 days of heat exposure each lasting 1 to 2 hours while performing physical exercise. In comparison, the South African and Australian mining 
industries do not have formal heat acclimatization guidelines. Instead, miners acclimatize naturally "on-the-job" in the hot mines over 12 work shifts (Leveritt, 1998; McPherson, 2011).

Enforcing structured hydration regimes are essential in reducing the effects of occupational heat stress. Severe dehydration may increase the risk of heat-related illnesses, by impairing thermoregulation and augmenting thermal (Sawka et al., 1985) and cardiovascular (Montain et al., 1992) strain, leading to a decrease in exercise-heat tolerance (Cheung and McLellan, 1998a; Sawka et al., 1992). Workers and medical personnel should however be alerted to the potential dangers of exercise-associated hyponatremia due to overdrinking during exercise in hot and humid environments (Lee et al., 2011). Exercise-associated hyponatremia is defined as having a plasma sodium concentration below $135 \mathrm{mmol} \cdot \mathrm{L}^{-1}$ within 24 hours of physical activity (HewButler et al., 2015). It is noteworthy that externally advocated hydration policies (especially based on change in body mass with exercise in healthy individuals) have limited merit and are extrapolated and imposed too widely upon society, at the expense of autonomy (Cotter et al., 2014). Moreover, the thirst mechanism in-built in humans cannot completely prevent dehydration (TBMED507, 2003). The hydration guidelines formulated by the US military specified volumes of water to be drunk for various work intensities and ambient temperatures (TBMED507, 2003).

Work-rest cycles involve alternating between periods of work and rest to limit excessive accumulation of body heat storage. Under uncompensable heat stress however, sustained heat gain beyond dissipation capacity from evaporation may still persist even during recovery (McLellan et al. 2013). The cooling process can be expedited through active cooling strategies such as arm immersion cooling (House et al., 1997; House et al., 2003; DeGroot et al., 2013) and ingestion of cold drinks (Lee et al., 2013) and potentially ice slurry (Yeo et al., 2012; Tan and 
Lee, in press). The U.S. military has formulated work-rest schedules for different combinations of physical workloads and weather conditions (TBMED507, 2003). The work-rest guidelines are implemented in average-sized and heat acclimatized soldier donning the battle dress uniform under hot weather conditions. For example, if moderate work $(425 \mathrm{~W})$ is performed in a WBGT of 29.4 to $31^{\circ} \mathrm{C}$, soldiers are to follow a 40-20 min work-rest regime. On the other hand, miners in South Africa are generally advised to take 10 to 15-min breaks every hour (Schutte, 2009).

\section{Heat stress standards and guidelines}

International bodies that control the health risk of occupational heat stress in workers have formulated heat stress standards/guidelines that specify upper limits of safe heat exposure. These standards/guidelines are generally based on preventing core temperature from exceeding $38^{\circ} \mathrm{C}$; because the risks of heat-related illness are magnified above this threshold (NIOSH, 2013). A summary of these standards/guidelines relating Wet-bulb Globe Temperature (WBGT) to the risks of sustaining heat illness is provided in Figure 2. Specifically, Figure 2 shows the respective WBGT threshold values that pertain to a low, moderate, high and very high risk of heat-related illnesses recommended by the various international organizations.

\section{Figure 2 about here.}

The ISO 7243 states WBGT threshold values for acclimatized workers undertaking various physical workloads. A threshold WBGT of $28^{\circ} \mathrm{C}$ applies to moderate workloads (234-360 W), while a WBGT of $25^{\circ} \mathrm{C}$ is applicable to heavy workloads (360-468 W) with low air velocity. The assumptions of the ISO 7243 are that the worker is healthy, physically fit for the required activity level, and wearing standard summer-weight work clothing with a thermal insulation value of around 0.6 clo (not including the still-air-layer insulation). 
The National Institute for Occupational Safety and Health (NIOSH) estimated exposure limits for unacclimatized (Recommended Alert Limit - RAL) and acclimatized (Recommended Exposure Limit - REL) workers (NIOSH, 2013). The RAL/REL is based on total metabolic heat production, expressed as a function of energy expenditure and exposure duration. For example, an acclimatized worker expending 349W for 45 minutes of work each hour has a WBGT limit of $\sim 27.5^{\circ} \mathrm{C}$. If the same workload was performed for 30 minutes each hour, the WBGT limit is $\sim 28.5^{\circ} \mathrm{C}$.

The Occupational Safety and Health Administration (OSHA) Standards Advisory Committee on Heat Stress (SACHS) has recommended WBGT limits of $30^{\circ} \mathrm{C}, 27.8^{\circ} \mathrm{C}$ and $26.1^{\circ} \mathrm{C}$ for light $(<233 \mathrm{~W})$, moderate $(234-349 \mathrm{~W})$ and heavy $(>349 \mathrm{~W})$ workloads, respectively (Ramsey, 1975). These limits are for continuous work with low air velocities not exceeding 300 fpm.

The American Conference of Government Industrial Hygiene (ACGIH) developed the Threshold Limit Values (TLVs) that define maximum allowable heat exposure limits (ACGIH, 2005). The TLVs range from WBGT limits of $30^{\circ} \mathrm{C}$ for light work $(117-233 \mathrm{~W}) ; 26.7^{\circ} \mathrm{C}$ for moderate work $(234-407 \mathrm{~W})$; and $25^{\circ} \mathrm{C}$ for very heavy work $(407-581 \mathrm{~W})$. The TLVs assume that the: (1) workers are acclimatized to the work-associated heat stress at the workplace, (2) workers are dressed in usual work clothing, (3) workers have sufficient water and salt intake, (4) workers should be capable of functioning effectively, (5) time-weighted average deep body temperature will not exceed $38^{\circ} \mathrm{C}$ and that (6) rest environment is approximately the same as the working environment.

Although the WBGT index for measuring environmental heat used in the above standards/guidelines is a widely used heat stress index, its limitations must be noted (Budd et al., 
2008; Lim and Song, 2000). These include: (1) failure to account for humidity and air movement, (2) underestimation of the stress of restricted evaporation, (3) measurement errors due to nonstandard instrumentation etc. and (4) not considering internal factors affecting heat strain (e.g. heart rate, metabolic rate and clothing).

It must be noted that the aforementioned heat stress guidelines and standards are generic and should be modified based on the specific context of its intended application. This would ensure that work is not unnecessarily limited, while concurrently minimizing the risk of heat-related illness.

\section{Environmental modifications}

Employers should foremost create a work environment that alleviates thermal stress on the employees. External strategies should be employed to reduce environmental heat to ensure that the thermal conditions in the workplace are within the recommended heat stress limits $\left(18-27^{\circ} \mathrm{C}\right.$ WBGT) outlined earlier. These strategies include rescheduling of work and engineering controls.

Rescheduling work to parts of the day where ambient temperatures are lower can reduce heat exposure and the thermal stress imposed on workers. At the Fukushima Dai-ichi nuclear power plant in Japan, work shifts are made to end at $1400 \mathrm{~h}$ to prevent exposure to the high temperatures between 1400-1700 h (Wada et al., 2012). Recently, researchers have also recommended a work pattern for construction workers in Hong Kong to maximize work productivity and capacity, while minimizing workers' risks of heat-related illness (Yi and Chan, 2014). This newly-proposed work pattern involves starting work 30 min earlier and having an additional 20 min rest break at mid-morning. However, there are occupations (e.g. military, firefighting) where rescheduling of work is not possible due to operational demands. In these occupations, ambulatory monitoring of body core temperature can be used to control work 
duration and prevent significant heat strain during work in the heat. For instance, personnel can be pulled out from the operation immediately when their core temperature reaches a certain threshold value. At present, the ingestible thermometer pill is the most common method for realtime body core temperature monitoring in field settings (O’Brien et al., 1998; Domitrovich et al., 2010). However, this method has several limitations such as its impracticality for frequent use and high cost. The U.S. Army Research Institute of Environmental Medicine is currently in the process of improving and enhancing the Warfighter Physiological Status Monitoring (WPSM) system (Friedl, 2007; Tharion and Kaushik, 2006). Future designs of the WPSM may overcome some of the constraints of the thermometer pill (RTO, 2010). In some occupational settings, engineering controls can be implemented to reduce environmental heat. For example, the Enterprise Mine at Mt Isa in Australia has implemented refrigeration systems that cool the air and reduce the ambient temperature in the mine (Brake and Fulker, 2000). However, such measures are costly and are irrelevant to many occupations where environmental conditions cannot be controlled (e.g. firefighting, military and agriculture).

\section{Physical employment standards in heat-related occupations}

Heat mitigation strategies are undoubtedly useful in alleviating the health risks of heat stress. However, they do not address the considerable inter-individual variability in the response to heat stress in relation to performance and heat-related illnesses. Individual factors that influence heat tolerance include level of aerobic fitness, heat acclimatization status, body composition, age, sex and certain genetic predisposition (Cheung and McLellan, 1998b; Havenith and van Middendorp, 1990; Havenith et al., 1995a, 1995b; Kaciuba-Uscilko and Grucza, 2001; Inoue et al., 2005; Wang et al., 2001; Lin et al., 1997). For example, highly-aerobically fit individuals were found to have superior exercise-heat tolerance compared to the less fit (Cheung and McLellan, 1998b). 
Regarding sex differences, women generally have a lower sweat response than men (KaciubaUscilko and Grucza, 2001; Inoue et al., 2005). In addition, women in the luteal phase of the menstrual cycle tend to have a higher core temperature at rest and during heat exposure, compared to women in the follicular phase (Inoue et al., 2005). This implies that some workers are able to tolerate higher heat loads than others without sustaining heat-related illnesses; and are hence more capable of working in hot environments. Therefore, the first line-of-defence against the health hazards of occupational heat stress should be the selection and recruitment of individuals who have the physical and physiological capacities to tolerate heat stress. The selection criteria to determine employability should be based solely on the minimum physical requirements to perform the job "safely and efficiently" (Tipton et al., 2013 and Jamnik et al., 2013). In other words, all workers who meet the criteria can be employed, regardless of sex and/or age.

There is a vast number of physical fitness tests and standards that have been implemented in occupations that carry a high risk of occupational injuries, in an effort to reduce such risks and optimize workforce productivity. For example, new employees at a food production plant and electrical equipment manufacturing facility who met the physical requirements of their jobs subsequently had a lower risk and rate of work-related musculoskeletal injuries than those who failed the test (Harbin and Olson, 2005). Similarly, at an industrial yard that distributes building materials, new employees who were screened and matched to the physical demands of the job were less susceptible to musculoskeletal injuries, compared to their unscreened counterparts (Rosenblum and Shankar, 2006). These findings highlight the importance of pre-employment physical fitness testing in minimizing the incidence of injuries in the workplace. Moreover, with 
fewer workplace injuries, health care costs to employers are reduced (Harbin and Olson, 2005; Rosenblum and Shankar, 2006; Anderson and Briggs, 2008).

Heat-related occupations, mainly firefighting and the military, also have a wide array of physical tests and standards for recruitment purposes and maintaining the physical fitness of existing personnel. However, these tests are seldom conducted under conditions that reflect the actual hot environments these workers are required to work in. Temperature specificity is critical since it is well known that exposure to heat stress reduces work capacity and increases the demands of the tasks (Dunne et al., 2013; and Galloway and Maughan, 1997). Performing a firefighter task of a given workload in a hot environment $\left(89.6^{\circ} \mathrm{C}\right)$ was found to be more physiologically taxing and strenuous than when performed under cool ambient conditions $\left(13.7^{\circ} \mathrm{C}\right)$ (Smith et al., 1997). Furthermore, combat fitness was poorer in the heat $\left(26.2^{\circ} \mathrm{C} ; 75 \%\right.$ relative humidity) than in a cooler environment $\left(19^{\circ} \mathrm{C} ; 22.7 \%\right.$ relative humidity) (Patterson et al., 2007). Thus, the assessment of physical capabilities under thermoneutral conditions may be a poor indicator of job performance in hot environments.

For valid standards to be developed, it is crucial to assess the physical demands of specific job tasks although accurate quantifications can at times be challenging. Field measurements of metabolic demand $\left(\dot{\mathrm{V}}_{2}\right)$ are often difficult to obtain. Furthermore, most testing equipment are not suitable for use in the heat (Tofari et al., 2013 and Siddall et al., 2014). As such, to accommodate the collection of metabolic data, task simulations are often used and studies are often conducted under temperate environmental conditions (Tofari et al., 2013 and Siddall et al., 2014). The trade-off may be the formulation of standards that have limited field relevance. For example, Lord et al. (2012) validated the Pack Hike Test and Field Walk Test - physical fitness tests for firefighters - and found that performance on both tests did not accurately predict 
performance on bushfire suppression tasks. That said, there are a limited number of physical tests in heat-related occupations that specifically assess applicants' capacity to undertake physical work in hot environments. A summary of these tests is presented in Table 1. These tests are currently in use by the respective occupations, except for the Hot Bruce test for HAZMAT workers that has yet to be implemented.

\section{Table 1 about here}

\section{Firefighting}

Perhaps one of the superior tests that considers the effects of the work environment on physical capability and job performance is the Trondheim test, developed by the Trondheim Fire Brigade in Norway for firefighter applicants (von Heimburg et al., 2013; von Heimburg and Medbo, 2013). The test, which was designed to assess physical capabilities specific to firefighting, requires participants to complete several firefighting task in three parts. The first and third parts of the test battery are conducted in a thermoneutral environment, and contain a mixture of physical (hose dragging, carrying heavy cans, tunnel-crawling etc.) and cognitive (puzzle-solving) tasks. Only the second part of the test is conducted in a heat chamber (air temperature of 120 to $140^{\circ} \mathrm{C}$ ), where applicants have to complete a physically demanding task of carrying concrete blocks up and down the stairs. Applicants must complete the entire test battery in 19 minutes or less to pass. It is however noteworthy that this proposed standard has yet to be verified (von Heimburg et al., 2013). Furthermore, this test may require further enhancement as it was found to be less predictive of muscular fitness (von Heimburg et al., 2013).

\section{Mining}

At Mt Isa mines in Australia, pre-employment medical and physical examinations are conducted to identify applicants with risks of heat illness (Brake et al., 1998). Those with an 
aerobic capacity $\left(\mathrm{V}_{2 \max }\right)$ below $30 \mathrm{ml} \cdot \mathrm{kg}^{-1} \cdot \mathrm{min}^{-1}$ or a body mass index (BMI) above 35 will not be employed. For existing miners, post-shift dehydration tests are necessary for those working at hot work sites (Brake et al., 1998; and Brake and Bates, 2003). Workers who pass the test are considered euhydrated and can return for the next shift, while those who fail will not be allowed to undertake the next shift unless they pass a re-test. Ensuring that the miners start the work shift in a euhydrated state is critical to optimizing heat tolerance capacity and hence lowering the risk of heat-related illness, as prior dehydration has been shown to impair exerciseheat tolerance during subsequent heat stress exposure (McLellan et al., 1999; Cheung and McLellan, 1998a). Whether this procedure would promote excessive drinking leading to exercise-associated hyponatremia needs to be further validated. Hydration status was initially estimated by administering a Fantus test that measures urinary chloride levels. Later, Brake and Bates (2003) recommended measuring urine specific gravity, quoting its practicality and reliability. Data from Brake and Bates (2000) found that following implementation of the preemployment examinations and dehydration tests, the total incidence of heat-related illnesses reported at Mt Isa mine were nearly halved from 31 to 18 cases per million man-hours. However, it must be noted that the pre-implementation data were collected over a 3-year period (1996 to 1998), while the post-implementation data were collected over a relatively shorter 2-year period (1998 to 1999). It is possible that the extent of the reduction is overestimated. Moreover, the figures only include cases that were medically reported.

Pre-employment medical and physical examinations are also conducted at South African mines. The exclusion criteria are: age $>50$ years old; body mass index $(\mathrm{BMI})>35$; body mass $<50 \mathrm{~kg}$; or previous heat disorders (McPherson, 2011; Schutte, 2010). Applicants who have at least two of these risk factors are immediately disqualified. Those who pass will proceed to the 
Heat Tolerance Screening (HTS) test, where applicants' thermoregulatory capacity will be tested. The HTS test comprises 30 minutes of bench-stepping exercise at an external work rate of $80 \mathrm{~W}$ in a heat chamber with a dry-bulb temperature of $29.5^{\circ} \mathrm{C}$, wet-bulb temperature of $28^{\circ} \mathrm{C}$, and air velocity of 0.3 to $0.5 \mathrm{~m} \cdot \mathrm{s}^{-1}$. Heat tolerance and hence fitness for duty is determined by the ability to maintain rectal temperature and/or heart rate below $38.9^{\circ} \mathrm{C}$ or 160 beats $\cdot \mathrm{min}^{-1}$, respectively, throughout the test (Leveritt, 1998; Kielblock, 1992). It is noteworthy that the bench-stepping exercise used in the HTS has little relevance to actual mining tasks. It is however is cheap, efficient and easy to administer to large groups of applicants.

The importance of the HTS was highlighted by Kielblock (1992), who noted that it helped to weed out more than 9,000 heat-intolerant workers who were subsequently barred from working in hot conditions. Furthermore, Schutte (2010) reported on data that support the effectiveness of the HTS. During a 3-year period before the HTS test was implemented, 83 cases of heat stroke and heat exhaustion were reported. During 2005 to 2007 after its implementation, this figure decreased by $60 \%$ to 33 cases (Schutte, 2010). These figures represent heat stroke and heat exhaustion cases. It is noteworthy that the 30 -min protocol may be insufficient to determine heat tolerance, as research suggests that a minimum of 90 minutes is required (Moran et al., 2004 and Shapiro et al., 1979).

\section{Military}

The Israeli Defence Forces (IDF) have also developed a test for assessing heat tolerance, called the Heat Tolerance Test (HTT) (Druyan et al., 2012; Kazman et al., 2013; O’Connor et al., 2007). Unlike the HTS that is administered to job applicants, the HTT is used on soldiers following an episode of exertional heat stroke to determine their recovery and whether they are fit to resume military duty. The HTT helps to minimize reoccurrence of heat-related illnesses 
(Shapiro et al., 1979). The protocol for the HTT is different from the HTS. The HTT involves 120 minutes of treadmill walking at $5 \mathrm{~km} \cdot \mathrm{h}^{-1}$ with a $2 \%$ incline, and is performed in a heat chamber with an ambient temperature of $40^{\circ} \mathrm{C}$ and $40 \%$ relative humidity (Moran et al., 2007; O’Connor et al., 2007). Soldiers are considered to be heat tolerant if during the test, their rectal temperature and/or heart rate does not exceed $38.5^{\circ} \mathrm{C}$ or 160 beats $\cdot \mathrm{min}^{-1}$, respectively; or either variable plateaus (Moran et al., 2004; Druyan et al., 2012).

The HTT has been in use by the IDF since 1983 and the investigators have suggested it is useful and effective for identifying heat intolerance (Lisman et al., 2014, Moran et al., 2007; Kazman et al., 2013). Soldiers who passed the HTT and fully resumed duty reportedly did not suffer a subsequent bout of heat injury (Epstein and Heled, 2013; McDermott et al., 2007). Several researchers also recommend using the HTT to assist in return-to-duty/play decisions for post heat-illness individuals (Kazman et al., 2013; McDermott et al., 2007; O'Connor et al., 2007). Yet, the U.S. military does not adopt the HTT for this purpose (Lisman et al., 2014; Kazman et al., 2013). The validity of the HTT has also been questioned (Johnson et al., 2013; O'Connor et al., 2010). For example, it is unclear whether the HTT can predict the occurrence of future heat-related illnesses (O’Connor et al., 2010). Furthermore, the standards used in the HTT may be biased against females (Lisman et al., 2014; Druyan et al., 2012). Compared to males, females were more likely to exceed the upper limits of heat tolerance set in the HTT and be deemed as heat intolerant; perhaps due to sex differences in physiologic make-up and thermoregulatory patterns (Lisman et al., 2014; Druyan et al., 2012). The issue of whether the standards should be modified for females is pertinent as more females are entering the military (Druyan et al., 2012). To our knowledge, there are currently no pre-employment screening tests 
used by the military. Nevertheless, the success of the HTT in the IDF suggests that pre-screening may be useful in reducing heat-related illness.

\section{Hazardous materials (HAZMAT)}

A recently developed test - i.e. Hot Bruce Test (HBT) - has been recommended for evaluating HAZMAT applicants (Raymond et al., 2014). The HBT was modified from the standard Bruce test (Bruce et al., 1963) currently in use to induce additional heat stress, which was achieved by having applicants wear an impermeable protective suit during the treadmill test. Data revealed that the level of thermal and physiological strain experienced during the HBT was similar to that encountered during actual HAZMAT work. Thus, the HBT was suggested to be more relevant for pre-employment testing of HAZMAT applicants than the standard Bruce test. As enforced by the International Association of Fire Fighters (IAFF), existing HAZMAT workers have to pass a pre-entry screening test before they are allowed to perform duties at the fire/HAZMAT scene. The passing criteria are: core temperature not above $37.2^{\circ} \mathrm{C}$; pulse rate not more than 100 beats $\cdot \min ^{-1}$; or blood pressure within $90 / 60$ to $150 / 90 \mathrm{mmHg}$. However, the circadian variation in core temperature is not accounted for (Aschoff, 1983; Kräuchi and WirzJustice, 1994). Furthermore, the anticipation and adrenaline rush of attending to the fire/HAZMAT incident can increase pulse rate and blood pressure.

\section{Cold stress}

Humans also respond strongly to regulate body temperature against heat loss in cold environments. Upon cold exposure, the initial physiological response is cutaneous vasoconstriction in order to decrease the conductive and convective thermal gradient between the body and the environment. This vasoconstriction can be extremely effective in reducing peripheral blood flow, with heat flow in the extremities $<0.1 \mathrm{~W}$ during hypothermia (Taylor et al. 2014). With continued cold exposure, the body attempts to forestall further heat loss by actively 
generating heat via shivering - the asynchronous and uncoordinated contraction of skeletal muscles that converts metabolic energy to heat energy with very high efficiency. Shivering can be highly effective in increasing heat production, ranging up to $1.5 \mathrm{~L} \cdot \mathrm{min}^{-1}$ oxygen consumption or 5-6 times resting metabolism (Bell et al. 1992). However, the tradeoff for this heat production includes a higher reliance on limited carbohydrate stores that can decrease work tolerance, strong perceptual discomfort that can affect cognition and the risk of unsafe behaviour, and decreased manual dexterity and motor coordination that can impair work performance or increase the risk of accidents. Finally, with prolonged cold exposure, there is some evidence of elevated nonshivering thermogenesis through metabolic or muscular changes. The evidence for physiological adaptations from longitudinal cold exposure is equivocal (Launay and Savourey 2009), with the dominant adaptation a perceptual habituation and desensitization to cold stress rather than largescale systemic physiological changes as seen with heat acclimatization. Despite population and longitudinal evidence of cold adaptation in the extremities through greater local blood flow and digit skin temperatures, this has largely not been observed in laboratory acclimation studies (Cheung and Daanen 2012).

\section{Health and occupational impact}

While climate change may have emphasized the occupational threats from hot environments, cold ambient temperatures will remain a significant factor in many outdoor and indoor work settings. However, research on the effects of cold on physical work capacity does not have a very long history. Henschel (1971) stated that: "Among the many articles published in the vast literature on the responses of man to cold stress, not one is directly concerned with physical work capacity in the cold." Since then more research has been conducted in several cold-related occupations. However, overall knowledge is still sparse and, even in more thoroughly researched industries such as food processing (Campbell 1999), the knowledge is not comprehensive. In 
addition, a fairly large amount or even a majority of the studies are related more on musculoskeletal complaints, symptoms and disorders rather than physical strain exerted by the work (Nordander et al. 2009; Pienimäki 2000). Therefore, the knowledge regarding workinduced physical strain in cold-related occupations, and therefore its impact on physical employment standards, remains to some extent diffuse.

Indoor cold working environments are especially prevalent in the food industry, from the actual processing of meats and seafood occurring in ambient temperatures of $0-10^{\circ} \mathrm{C}$ through to cold storage at temperatures below $-20^{\circ} \mathrm{C}$ (Makinen and Hassi 2009). Cold outdoor work can be seasonal in nature, such as in the construction industry. However, particular occupations - such as electrical and telecommunications repair crews - can face particularly extreme weather conditions such as ice storms and blizzards. Outdoor work can also be cold throughout the year, notably in marine occupations such as fishing.

Some direct hazards from occupational cold exposure include (Figure 3):

\section{Figure 3 about here}

- The sustained breathing of cold air affects the respiratory system. While some laboratory studies propose minimal physiological effect or discomfort from acute breathing of cold air down to $-35^{\circ} \mathrm{C}$ (Hartung et al. 1980), the irritation from cold air can elicit bronchospasms and asthma incidents in susceptible individuals (Carlsen 2012). Longer term epidemiological studies also suggest an association between prolonged cold air exposure with respiratory issues such as chronic obstructive pulmonary disease (COPD) (Tseng et al. 2013). 
- Even brief cold exposure may elevate hormonal stress markers and potentially impair immune function (LaVoy et al. 2011), which can increase the rate for respiratory tract infections (Mourtzoukou and Falagas 2007). The risks may also be independently increased or synergistically exacerbated by exercise due to the greater total ventilation.

- Musculoskeletal injuries are another direct health impact from cold working environments (Figure 4), with lower back and knees the most common sites of complaint along with an increased prevalence of repetitive strain injuries such as carpal tunnel syndrome (Pienimäki 2002). Progressively colder temperatures increase the prevalence of self-reported musculoskeletal pain, with a transposition towards higher threshold temperature for southern compared to northern residents in Finland (Pienimäki et al. 2014).

\section{Figure 4 about here.}

- Cold exposure can lead to direct tissue injury. This can occur from direct contact with cold materials rapidly cooling local skin temperatures (Geng et al. 2006). Alternately, prolonged extremity cold exposure and tissue cooling to near-freezing temperatures can lead to non-freezing cold injuries, and this can be exacerbated by contact with cold water leading to clinical issues such as immersion foot (Imray et al. 2011). With continued cooling, the extremities or exposed skin can freeze and crystallize, leading to frostbite. Historically, frostbite and other cold injuries have been a leading health and operational risk in military settings, but can be common in numerous other outdoor occupations (Hamlet 1988; Imray and Oakley 2005). 
Cold outdoor scenarios can often be magnified by other environmental stressors, including darkness during winter months, and also hypoxia due to decreasing temperatures at altitude.

Other commonly occurring co-factors with cold environments include cold water increasing the rate of heat loss or risk of non-freezing cold injuries (e.g., immersion foot), and the requirement for bulky protective clothing decreasing mobility while increasing metabolic cost of exercise. Cold exposure can also indirectly create or magnify hazards in the workplace through physiological or psychological changes. Chief amongst indirect hazards posed by cold is that from decreased manual function (Heus et al. 1995), which can rapidly impair task performance and increase the risk for accidents or intensify a dangerous situation. For example, the inability to operate escape systems or remove oneself from a high heat loss situation can lead to eventual death by hypothermia. Cold can also decrease vigilance and impair cognitive performance, magnifying the risk from inappropriate mental actions leading to accidents (Flouris et al. 2007; Hancock et al. 2007; Pilcher et al. 2002). This can be seen in a 16\% decrease in driving performance in cold $\left(5^{\circ} \mathrm{C}\right)$ compared to neutral $\left(20^{\circ} \mathrm{C}\right)$ environments (Daanen et al. 2003). Cold environments often have decreased traction through the presence of condensation, ice, or snow, with greater risks for slips and falls. These indirect hazards may be magnified by age-related decrements in strength, proprioception and motor control, or cognitive function. Finally, cold extremity temperatures appear to be a complementary factor in the risk and severity of hand-arm vibration syndrome in users of vibratory equipment such as jackhammers, chainsaws, or snowmobiles (Carlsson and Dahlin 2014).

\section{Future projections}

Working life is in continuous change. Where "traditional" cold-related occupations such as forestry was in the 1980 's found to be very strenuous $(65 \%$ of the working time cardiovascular strain between $50-57 \% \dot{\mathrm{VO}}_{2 \max }$, Kukkonen, 1982), its nature due to mechanization and 
digitization has changed it towards a more sedentary type of work. In addition, along with societal trends such increasing tourism in the arctic and subarctic areas, "new" occupations have emerged. These include wilderness guides, ski-instructors, ski resort workers and search \& rescue workers, but research regarding these and other similar emerging occupations is lacking.

\section{Work in the cold}

Occupational cold exposure can vary greatly. Due to the large metabolic heat production from exercise, the magnitude of heat loss can be modified by the activity level. Thus, the effect of $10^{\circ} \mathrm{C}$ exposure for a sedentary office worker can differ greatly compared to an active occupation. The same disparity can also occur within a particular occupation or work shift, such as military personnel during watch duty compared to marching. Finally, the degree of clothing can greatly modify the impact of cold exposure. The following section reviews some of the existing research into occupational cold exposure, categorized amongst different industries.

\section{Food processing}

Food processing, comprising mostly of meat, poultry and fish processing, meat cutting and cold storage workers, is one of the more intensively-studied industries in terms of cold impact. The main research tools consist of questionnaires, interviews and subjective evaluations, whereas actual physiological measurements are also utilized. The studies regarding actual measurements have focused mostly on thermal and muscular strain, and to a lesser extent on cardiovascular strain. Regarding cardiovascular strain it has been found that, while working in cold storage rooms $\left(-26^{\circ} \mathrm{C}, 0-10^{\circ} \mathrm{C}\right.$ and $\left.10-14^{\circ} \mathrm{C}\right)$, the average metabolic rate varied between $750-2020 \mathrm{kcal}$ per work shift and heart rate (HR) between $67-86$ beats $\cdot \min ^{-1}$. No significant differences between the different categories of working temperatures were observed. The large variation in metabolic rate was due to significant differences between work shift durations, varying from approximately 5 to 18 hours (Bortkiewicz et al. 2006). In the study of Kluth et al. (2012) HR 
rose above the resting level in senior workers $(40-65 \mathrm{y})$ by $\sim 30$ beats $\cdot \mathrm{min}^{-1}$ and in younger workers (20 - 35 y) by $\sim 35$ beats $\cdot \mathrm{min}^{-1}$. In Chinese cold store workers heart rate was above 100 beats $\cdot \min ^{-1}$ for $3.7 \%$ and $2.4 \%$ of the working time at -15 to $-25^{\circ} \mathrm{C}$ and -5 to $5^{\circ} \mathrm{C}$ stores, respectively (Chen et al. 1991). In the study of Oliveira et al. (2014) the estimated metabolic rate in cold chambers $\left(\sim-17^{\circ} \mathrm{C}\right)$ was $151 \mathrm{~W} \cdot \mathrm{m}^{-2}$ and in cool chambers $\left(\sim 4^{\circ} \mathrm{C}\right) 161 \mathrm{~W} \cdot \mathrm{m}^{-2}$.

In general, muscular strain in food processing work has been found to be higher in relation to similar work in thermoneutral conditions (Sormunen et al. 2009). Higher strain and thus fatigue may be associated to low working temperature, high repetitiveness, awkward postures and considerable use of force (Christensen et al. 2000; Oksa et al. 2002; McGorry et al. 2004). In meat packing work the highest muscular strain was found in wrist extensor muscles being 16 $18 \% \mathrm{MEMG}$ (percentage of maximal electromyographic activity). Respective values in wrist flexor muscles were $8-12 \% \mathrm{MEMG}$, in trapezius $8-14 \% \mathrm{MEMG}$ and in shoulder region 6 $7 \%$ MEMG (Sormunen et al. 2006). In a simulated sausage packing work the strain focused on the upper extremity and neck shoulder regions; high values were also found in wrist extensor muscles in females $(<20 \% \mathrm{MEMG})$ and in males (<16\%MEMG) (Sormunen et al. 2009). These results are confirmed in the study of Arvidsson et al. (2012) where the highest \%MEMG values in meat cutters were found in wrist extensor muscles. In addition to high muscular strain, neuromuscular efficiency (workload divided by EMG activity) and maximal wrist flexion force are reduced more in repetitive work in cold than in thermoneutral condition (Oksa et al. 2002; 2012). Furthermore, manual dexterity is deteriorated in cold storage work (Tochihara et al. 1995), and to a greater extent during night shifts (Tochihara 2005).

Thermal strain of a worker is conventionally depicted by temperatures of the core (rectal, esophageal or tympanic) and skin (both mean and local temperatures). In meatpacking work 
where the ambient temperature varied between $4-10^{\circ} \mathrm{C}$, rectal temperature during an average 3.5 hour working bout remained stable between $37.2-37.4^{\circ} \mathrm{C}$, whereas mean skin temperature decreased from $\sim 31.5$ to $\sim 29.6^{\circ} \mathrm{C}$. As may be expected, peripheral parts of the body were the most susceptible for cooling, with finger temperature decreasing the most by $5.3^{\circ} \mathrm{C}$ (Sormunen et al. 2006). In an experimental study (intermittent exposure to $-24^{\circ} \mathrm{C}$ chamber for 60 minutes) with cold store workers and controls, it was found that rectal temperature (starting from the same thermoneutral level) declined less in workers compared to controls $\left(-0.5\right.$ and $-0.7^{\circ} \mathrm{C}$, respectively) (Tochihara 2005). This implies cold adaptation of the workers due to their frequent exposure to cold at work. In a study by Oliveira et al. (2005) it was predicted that 4 hour exposure to a freezing chamber with temperature below $-20^{\circ} \mathrm{C}$ would decrease rectal temperature from $\sim 36.8$ to $\sim 36.5^{\circ} \mathrm{C}$ and mean skin temperature from $\sim 33.7$ to $\sim 26^{\circ} \mathrm{C}$. Depending on the core temperature measuring site one may encounter quite different results when working in fairly similar conditions. Baldus et al. (2012) exposed 15 young (20 - 35 years) and 15 senior ( 40 - 65 years) workers to a chill room $\left(3^{\circ} \mathrm{C}\right)$ and cold store $\left(-24^{\circ} \mathrm{C}\right)$ for 80,100 and 120 minutes with 20 minute warming periods in between. The decrease in tympanic temperature was smaller with younger subjects from $37.0^{\circ} \mathrm{C}$ to $\sim 35.9^{\circ} \mathrm{C}$ at the end of last 120 minute exposure, whereas the equivalent values for seniors were from $36.9^{\circ}$ to $\sim 35.6^{\circ} \mathrm{C}$. As expected, also in this study the most susceptible body parts for cooling were the extremities: nose, feet, hand, toes and fingers (Baldus et al. 2012). These results indicate that changes in body core temperature are not substantial and do not jeopardize work ability. However, local skin temperatures in the extremities may be reduced to such extent that touch and manual and finger dexterity may be hampered.

Many adverse health effects have been reported regarding work in the food processing industry (Campbell 1999). The main health risks are related to musculoskeletal complaints, 
symptoms and disorders. For example, increased odds ratio for low back pain (Dovrat \& KatzLeurer 2007), upper extremity and neck disorders (Lipscomb et al. 2007) and carpal tunnel syndrome and degenerative discopathies (Pienimäki 2000) has been reported. In addition, women seem to be at higher risk compared to men due to the more repetitive nature of their work (Nordander et al. 1999). In addition to adverse health effects due to working in cold also cold related injuries in the food processing industry occur. These include e.g. slips and falls, musculoskeletal trauma, skin irritation and frostbites and nips (Sinks et al. 1987, Campbell 1999, Buzanello \& Moro 2012). These injuries have significance in terms of workers health since e.g. in the U.S. meatpacking industry has been reported to have the third highest injury rate among all manufacturing industries (Campbell 1999).

\section{Fishing}

Fishing has been reported to be the most hazardous occupation due to several factors such as cold stress, wind, slipperiness, rough seas and injuries and the majority of the available literature has focused on that aspect (Jelewska et al. 2012; Percin et al. 2012; Roberts 2010). The review of Matheson et al. (2001) reports annual mortality rate (cases/1000) to vary between 1.3 - 5.7. Roberts (2010) reports that in UK there are 102 fatal accidents / 100,000 fishermen-year the major reason for the accidents being "washed overboard" for several different reasons. This accident rate is 115 times higher than in general British workforce (Roberts 2010).

The literature regarding physical strain of fishing is sparse but some studies can be found reporting the cardiovascular strain of the fishermen. Rodahl and Vokac (1977) reported that, in long line bank fishermen, their maximal oxygen consumption varied between $2.9-3.3 \mathrm{~L} \cdot \mathrm{min}^{-1}$ and maximal HR $\left(\mathrm{HR}_{\max }\right) 190$ - 205 beats $\cdot \mathrm{min}^{-1}$. Their average work HR varied between 99 106 beats $\cdot \min ^{-1}$ and heart rate reserve (HRR) between $8-72 \%$. Unhooking the fish was the most 
strenuous work phase were HR varied between $145-165$ beats $\cdot \mathrm{min}^{-1}$. In other studies consisting of following fishing types; hand line, long line, net, Danish seine and "common for all types" average oxygen consumption varied between $0.8-1.7 \mathrm{~L} \cdot \mathrm{min}^{-1}$ corresponding to $23-$ $55 \% \dot{\mathrm{V}} \mathrm{O}_{2 \max }$ with peaks above $80 \% \dot{\mathrm{V}} \mathrm{O}_{2 \max }$ (Rodahl et al. 1974; Rodahl and Vokac 1979). Based on these results it may be considered that cardiovascular strain in fishing work is moderate to heavy. In fact, Jelewska et al. (2012) recommend that cardiovascular fitness and muscular strength of the fishermen should be on the level of "good."

\section{Construction}

A very recent study showed that physical fitness level of construction workers decreases with age (Jebens et al. 2015), which is well in line with other studies regarding aging population (Ilmarinen 2001). The senior (44-62 years) construction workers $\dot{\mathrm{V}} \mathrm{O}_{2 \max }$ was $39.5 \pm 7.0 \mathrm{ml} \cdot \mathrm{kg}^{-}$ ${ }^{1} \cdot \mathrm{min}^{-1}$ with $\mathrm{HR}_{\max }$ of $181 \pm 11$ beats $\cdot \mathrm{min}^{-1}$ and younger (21-33 years) workers $\dot{\mathrm{V}} \mathrm{O}_{2 \max }$ was $53.4 \pm 8.3 \mathrm{ml} \cdot \mathrm{kg}^{-1} \cdot \mathrm{min}^{-1}$ with $\mathrm{HR}_{\max }$ of $200 \pm 8$ beats $\cdot \mathrm{min}^{-1}$. The relative cardiovascular strain in senior workers was $33.4 \pm 9.3 \% \dot{\mathrm{V}} \mathrm{V}_{2 \max }$ and $\mathrm{HR} 97 \pm 15$ beats $\cdot \mathrm{min}^{-1}$ and in younger $25.1 \pm 7.8 \% \dot{\mathrm{V} O} \mathrm{O}_{2 \max }$ and HR $104 \pm 17$ beats $\cdot \mathrm{min}^{-1}$. Depending on the recommendation for acceptable cardiovascular strain the senior workers are partly overexerted $\left(33 \% \dot{\mathrm{V}} \mathrm{O}_{2 \max }\right.$ recommendation, Ilmarinen et al. 1992) or not (50\% $\dot{\mathrm{V}}_{2 \max }$, Andersen et al. 1978). Muscular strength level was fairly similar in both age groups and only hand grip force was significantly higher in younger workers (Jebens et al.2015). The study of Åstrand (1988) showed that both older (65 years) and younger (35 years) construction workers self-paced their work to correspond to approximately $40 \% \dot{\mathrm{V}} \mathrm{O}_{2 \max }$ level. In addition to cardiovascular strain, construction work also poses demands on the musculoskeletal system. Hartmann and Fleischer (2005) reported that in scaffolders and bricklayers, the pressure to the L5/S1 disc often exceeded $3.4 \mathrm{kN}$ and that 
bricklayers worked in bent postures $\sim 21-36 \%$ of their working time. These kind of working postures/conditions easily lead to often experienced musculoskeletal problems in construction work (Arndt et al. 2005).

\section{Mast and pole}

Literature regarding mast and pole work (or work in height) is also quite sparse. Kiparski and Massman (1982) studied 11 technicians climbing up to 135 meter mast and recorded HR levels between $178-184$ beats $\cdot \min ^{-1}$ during ascending and 170 beats $\cdot \min ^{-1}$ during descending. The EMG activity measured from $m$. vastus lateralis corresponded to that from bicycling at 150 W. The study of Klimmer et al. (1990) evaluated the cardiorespiratory strain of climbing into a revolving tower crane higher than 30 metres as very heavy. Parkhouse and Gall (2004) reported that older powerline technicians (over 50 years) climbed up to masts less often than younger workers, but that this was offset by an increased amount of pulling and pushing work on the ground level. Quite recent field study evaluated muscular, cardiovascular and thermal strain of 14 mast and pole workers in a temperature range of $-30-28^{\circ} \mathrm{C}$ (Oksa et al. 2014). The study divided mast and pole work into four categories: work on ground, ascending to the mast, work on height and descending from the mast. The average $\dot{\mathrm{V}} \mathrm{O}_{2}$ was $40 \pm 4 \mathrm{ml} \cdot \mathrm{kg} \cdot \mathrm{min}^{-1}(11.4 \pm 1.1 \mathrm{times}$ resting metabolic rate) and $\mathrm{HR}_{\max } 175 \pm 10$ beats $\cdot \mathrm{min}^{-1}$. The average metabolic strain during the whole working day was $48 \pm 3 \% \dot{\mathrm{V}} \mathrm{O}_{2 \max }$ and varied between $48-62 \% \dot{\mathrm{V}} \mathrm{O}_{2 \text { max }}$ in different work categories, with the highest strain found during ascending. The higher recommendation of $50 \% \dot{\mathrm{V}} \mathrm{O}_{2 \max }$ was exceeded in $40 \%$ of the subjects. Average working HR was $108 \pm 13$ beats $\cdot \mathrm{min}^{-1}$ and varied between $61-73 \%$ from $\mathrm{HR}_{\max }$. The highest muscular strain was systematically found in the forearm (15-33\%MEMG) and lower back muscles (11-16\%MEMG), almost always exceeding the $14 \%$ MEMG recommendation (Jonsson 1982). A significant correlation between 
lowering mean skin temperature and increasing muscle strain was found for upper arm and lower back muscles. Thermal strain remained in a tolerable level but a significant correlation between mean skin and ambient temperature was found (Oksa et al. 2014).

\section{Mining}

A very recently completed project called "MineHealth" tracked the cardiovascular, muscular and thermal strain during work in 23 workers at two arctic open-pit mines located in Finland and Sweden. The ambient temperature during the study varied between -0.7 to $-15.4^{\circ} \mathrm{C}$. The average cardiovascular strain was $33 \pm 3 \% \dot{\mathrm{V}} \mathrm{O}_{2 \max }$, and the highest values were observed during shoveling and hammering, well above $50 \% \dot{\mathrm{V}} \mathrm{O}_{2 \max }$. The average muscular strain remained below the recommended $14 \% \mathrm{MEMG}$, but exceeded it occasionally for short periods. Average core temperature was $37.4 \pm 0.3{ }^{\circ} \mathrm{C}$ and varied between $36.3-38.2^{\circ} \mathrm{C}$. Corresponding figures for mean skin temperature were $32.0 \pm 1.5^{\circ} \mathrm{C}$ and $28.0-36.3^{\circ} \mathrm{C}$. Out of the total working time the mean skin temperature was below $30{ }^{\circ} \mathrm{C}$ for $26 \%$ and the local skin temperatures of the hands below $15^{\circ} \mathrm{C}$ for $20 \%$ of the working time. (www.minehealth.eu). These results indicate that the level of physical strain in modern days mining work is on an acceptable level but more attention should be paid for reducing cold stress during work.

\section{Military}

The study of military work has a fairly long history through to recent times. Basic military training in the Swiss army induced average daily energy expenditure of $10.5 \pm 2.4 \mathrm{MJ}$, and the authors conclude it to be in the same order as in the armed forces of other nations (Wyss et al. 2012). Considerably higher average daily energy expenditure of $19.8 \pm 1.8 \mathrm{MJ}$ was found during an arduous 8-week military training course (Richmond et al. 2014). In terms of HRR, similar cardiovascular strain values during basic training for female $(31 \pm 4 \%)$ and male $(32 \pm 5 \%)$ in British recruits were found (Richmond et al 2012), but also differences have been reported 
depending on whether single or mixed gender platoon was studied (Blacker et al. 2009). In addition, Williams (2005) reported that basic training was able to increase $\dot{\mathrm{V}} \mathrm{O}_{2 \max }$ by $13.1 \pm 7.6 \%$ from the basic $44 \mathrm{ml} \cdot \mathrm{kg} \cdot \mathrm{min}^{-1}$ level. During a 4-hour road march with $43 \mathrm{~kg}$ weight the average HR was $139 \pm 18$ beats $\cdot \min ^{-1}$, corresponding to $73 \pm 7 \% \mathrm{HR}_{\max }$. A 14 hour simulated battle exercise induced average $\mathrm{HR}$ of $91 \pm 16$ beats $\cdot \min ^{-1}\left(45 \pm 5 \% \mathrm{HR}_{\max }\right)$, ranging from $55 \pm 11$ to $156 \pm 13$ beats $\cdot \min ^{-1}$ (Grenier et al. 2012). These exercises also induced a reduction in maximal voluntary isometric (MVC) knee extension and plantar flexion force of $\sim 10 \%$ (Grenier et al. 2012). Another load carriage study (19.3 km distance, $4.2 \mathrm{~km} \cdot \mathrm{h}^{-1}$ speed and load $31 \mathrm{~kg}$ ) at an average ambient temperature of $13.4^{\circ} \mathrm{C}$ induced average $\mathrm{HR}$ of $147 \pm 10$ beats $\cdot \mathrm{min}^{-1}$ (Fallowfield et al. 2012).

During military field training sessions performed at 0 to $-29{ }^{\circ} \mathrm{C}$ ambient temperatures, cooling was always superficial and peripheral. Average rectal temperature was $37.5 \pm 0.3{ }^{\circ} \mathrm{C}$ and varied between $36.6-38.5^{\circ} \mathrm{C}$. Mean skin temperature values below $27^{\circ} \mathrm{C}$ were frequent and found in all temperature ranges (Rintamäki et al. 2004). At temperature range of 0 to $-20{ }^{\circ} \mathrm{C}$ finger skin temperature was below $13{ }^{\circ} \mathrm{C}$ for $20 \%$ of the exercise time and when temperature decreased below $-20{ }^{\circ} \mathrm{C}$ the value increased to $69 \%$ (Rintamäki et al. 2004). It is evident that these changes in mean and local skin temperatures are able to hamper physical performance capability however, no cold injuries were reported during this field training exercise. In addition, both heat and cold strain may occur simultaneously in cold conditions, with the torso experiencing heat while peripheral parts of the body experience cold strain (Rintamäki and Rissanen, 2006).

Occupational neck disorders and high-G related neck pain are more frequent among fighter pilots in northern squadron compared to squadrons further south (Sovelius et al. 2007). It has 
been shown that, while exposed to $\mathrm{G}$ forces $\sim 4 \mathrm{G}$ and cold environment $\left(-2^{\circ} \mathrm{C}\right)$, muscle strain increases $2.6 \%$ for every $1{ }^{\circ} \mathrm{C}$ decrease in skin temperature. It has also been shown that during cold season (to which pilots in northern squadron are exposed more frequently), skin temperature over $m$. trapezius decreased from $30.1 \pm 1.7$ to $27.8 \pm 2.6^{\circ} \mathrm{C}$ during walk to the aircraft and before take-off (exposure duration 16 \pm 3 minutes) (Sovelius et al. 2007). This increases muscle strain, especially in the early phases of the flight mission and may be one reason for more frequent occurrence of neck problems.

\section{Physical employment standards in cold-related occupations}

Regarding all occupations the amount of physical employment standards reported in the literature is quite scarce, possibly due to their being technical reports and/or private company funded projects. Another reason may be that requirements for valid standards may be challenging. When determining fitness standards four areas should be considered; 1) the tasks on which to base the standard, 2) what is the minimum acceptable performance for the execution of these tasks, 3) what are physical demands of the task and relative workload and 4) producing the final standard (Tipton et al. 2013). It would also be desirable that the tests would cover the main components affecting physical performance capability: aerobic capacity, muscular strength, motor coordination, flexibility and body composition.

For cold-related occupations the review of Jackson (1994) reported validated preemployment tests for outdoor telephone craft jobs (involving pole climbing), electrical transmission line workers and military. Malmberg (2011) reported the physical fitness tests used in the Nordic (Finland, Sweden, Norway and Denmark) armed forces. Even in these examples of well-structured and validated test batteries some main component(s) of physical performance were missing, quite often body composition. This may just reflect the variability in the 
requirements and needs of a given occupation rather than an inadequately structured test battery. In some cases the need for a test battery may arise from legislation. According to Finnish occupational safety and health legislation (Occupational safety 2002, Occupational health care 2001), work that contains a particular risk of accidents (such as mast and pole work) must only be performed by workers that have been found (by occupational health care) suitable for that particular work. Therefore, a study regarding Finnish mast and pole workers was conducted to create a test battery consisting of all main components of physical performance (Oksa et al. 2011).

However, none of these test batteries have taken into account the effect of cold itself as a performance modifier. It is known that cooling and/or cold protective clothing increases physical strain of a given submaximal workload and that maximal performance capability can decrease. In a study of Oksa et al. (2004) it was found that maximal aerobic capacity decreased by $\sim 5 \%$ in a temperature range from 20 to $-20^{\circ} \mathrm{C}$ and submaximal strain increased by $\sim 14 \%$ in a temperature range from 20 to $-15^{\circ} \mathrm{C}$. Therefore, tests performed in a thermoneutral condition may underestimate the physical requirement for maximal aerobic capacity needed while working in cold. One of the few good example of where the working environment is taken into account when creating occupationally adapted fitness standards was presented by Reilly et al. (2006a and b). They first defined physiological demands of beach lifeguarding (Reilly et al. 2006a) and then administered fitness tests in the water environment (Reilly et al. 2006b).

The reason why fitness requirements may be set is to guarantee that work can be performed safely and that the health of the worker or their colleagues is not jeopardized. The requirements (or sometimes recommendations) are often set by the employer or external experts and generally the goal is to achieve "good" or "normal" fitness level. In some occupations, such as mast and 
pole work, achieving the requirements may be a prerequisite for a license to perform a certain work; in this case climb onto a mast. For example, on a bicycle ergometer test the workers are required to achieve $3 \mathrm{~W} \cdot \mathrm{kg}^{-1}$ peak power output before the license may be granted (Oksa et al. 2011). Another approach is to grade fitness levels where at least the "minimum" must be achieved. This approach is in use in the Danish and Norwegian armed forces (Malmberg 2011). It has been shown that working in cold conditions induce higher level of physical strain and reduced maximal working capacity than similar work in thermally neutral conditions (Oksa et al. 2004). Therefore, to have a same level of relative strain in cold requires higher fitness level as compared to work in thermoneutral conditions.

The guidelines can be roughly divided into technical/organizational and individual actions. International Standardization Organization has provided standard organizational and technical preventive measures against cold risks both in outdoor and indoor work. These include a multitude of actions that should be taken into account in the planning phase of different projects and in the workplace before starting the work and during it (ISO 15743). Similarly, Keim et al. (2002) have provided a list regarding engineering, administrative and personal protection controls that should be implemented to reduce cold stress (Table 2).

\section{Table 2 about here}

At an individual level, the literature reports few methods that can directly enhance work ability in cold. It has been found that aerobic training increases work ability in farmers (PerkiöMäkelä 1999) and strength training increases both work ability and reduces musculoskeletal pain in slaughterhouse workers (Sundstrup et al. 2014). The use of active microbreaks in meat packing plants was also found to reduce musculoskeletal discomfort (Genaidy et al. 1995). It is also reported that in simulated packing work (at $4^{\circ} \mathrm{C}$ ), increasing work intensity every 4 minutes 
from $10 \% \mathrm{MVC}$ to $30 \% \mathrm{MVC}$ is able to reduce muscular strain and fatigue and thus enhance work ability (Oksa et al. 2006a). Therefore, it is recommended that during low intensity repetitive work the monotonous work pace should be changed at least every 10 minutes to a slightly higher pace. When trying to achieve as high a level of motor skill as possible for cold work, it is most beneficial to train the skill first in thermoneutral environment and then in cold rather than training only in thermoneutral or cold environment (Oksa et al. 2006b). As work in cold requires higher fitness level than work in thermoneutral conditions it is recommended that people in cold related occupations should exercise on regular basis to achieve good fitness level. Relating to this appropriate and valid test batteries for evaluating physical fitness level should be created.

\section{Conclusions and future research}

Overall, while there is a large body of knowledge concerning the physiological effects of thermal stress, work into direct occupational applications such as developing physical employment standards can be considered to be in its infancy. Physical employment standards are largely non-existent in most cold-related occupations. In hot environments, current standards tend towards being based on isolated factors - such as aerobic fitness - that indirectly contribute to improved work performance but yet may not be the sole or key limiter in the majority of situations. Physical employment standards are currently limited to firefighting, military and mining occupations, yet there are other occupations that expose workers to excessive heat stress but do not perform pre-employment physical testing. These occupations include agriculture, construction, manufacturing and factory workers. In occupations that are largely in the informal sector, it will be difficult to enforce such regulations. It would therefore be useful to identify 
feasible methods to raise awareness among employers and employees about the hazards and risk factors of heat stress in these occupations, and how to reduce the associated health risks.

The core feature of a valid PES is that the performance criteria are representative of the minimum physical demands of the job. As such, cut scores on PES for applicants are commonly derived from the performance of incumbents on the tests (Jamnik et al., 2013). This is however only applicable to occupations that require applicants to start work immediately following employment (e.g. mining). In such cases, it is reasonable to expect applicants to have the same level of physical fitness as incumbents in order to be employed. For other occupations (e.g. military and firefighting) where successful applicants typically go through a training period prior to deployment, the criteria on the PES should be lower than the actual job demands. This is because training will enhance physical fitness and task performance (Harman et al., 2008; Knapik et al., 2009); thermal tolerance may also improve as a result of physical training (Aoyagi et al., 1994; Cheung and McLellan, 1998b). A review by Jamnik et al. (2013) reported that wildland firefighting applicants could expect an 18 to $23 \%$ improvement in performance after undergoing six weeks of physical fitness training. This performance improvement must be taken into account when determining the cut scores for applicants (Tipton et al., 2013); otherwise, the standards would be too stringent and eliminate applicants who would be fit for the job.

Some of the future research into thermal issues relevant to physical employment standards include the following issues:

- How does the use of protective clothing, which typically impairs heat exchange with the environment, affect cut scores and PES design? Similarly, how does the use of heat mitigation strategies - both individually and systemically - affect PES requirements? 
This is especially an issue with the progressively greater use of protective clothing or encapsulation in many occupations (e.g., security, first responder).

- How should PES accommodate prolonged work (e.g., musculoskeletal strain) that may limit work capacity without causing whole-body fatigue from traditional physiological (e.g., core temperature or heart rate) measures? This is especially relevant to work in the cold, due to both decreased neuromuscular capacity and co-factors such as vibration.

- What are ways to integrate "recovery" into PES? Cumulative fatigue may be regarded as a precursor for musculoskeletal complaints, symptoms and disorders (Buckle \& Devereaux 1999). One reason for this may be insufficient recovery from work before the next work bout. Practically nothing is known of the speed and dynamics of the recovery processes and of the use of active recovery methods (to enhance recovery) after cold work.

- How can individual variability (e.g., sex, age) in response to thermal stress be integrated into PES without making the standards cumbersome? Furthermore, given the known decrements in thermoregulation and thermal tolerance with aging (Kenny et al. 2008), how frequently should PES be performed on incumbents?

- Also relevant to the testing of incumbents, how does long term thermal exposure affect work capacity? The short term effects of cold on human function are quite well documented, however there is a gap in the knowledge concerning long term effects. This is especially important since in cold- and hot-related occupations the adverse health effects are pronounced in relation to work in thermoneutral environment. At the moment 
we are not well aware of the mechanisms inducing these pronounced and negative health effects and this line of research would need more focus.

A holistic and systematic approach to tackle these issues would certainly benefit, not only the employee and the employer, but also the whole society both economically and health wise.

\section{Acknowledgements}

We wish to thank Beverly Tan for her consolidation of the literature and administrative support. S.S. Cheung is supported by a Canada Research Chair.

\section{Disclosures}

The author declares that there are no financial or other conflicts of interest to disclose.

\section{References}

American College of Sports Medicine. 1984. Prevention of heat injuries during distance running. A position statement from the American College of Sports Medicine. J. Sports Med. 3(4): 194-196.

American Conference of Governmental Industrial Hygienists. 2005. Threshold limit values for chemical substances and physical agents and biological exposure indices, heat stress and heat strain. ACGIG, 181-188.

Andersen, K.L., Masironi, R., Rutenfranz, J., and Seliger, V. 1978. Habitual physical activity and health. WHO Regional Publications European Series No. 6. Copenhage: WHO. Anderson, C., and Briggs, J. 2008. A study of the effectiveness of ergonomically-based functional screening test and their relationship to reducing worker compensation injuries. Work. 31(1): 27-37. 
Aoyagi, Y., McLellan, T.M., and Shephard, R.J. 1994. Effects of training and acclimation on heat tolerance in exercising men wearing protective clothing. Eur. J. Appl. Physiol. Occup. Physiol. 68(3): 234-245.

Arbury, S., Jacklitsch, B., Farquah, O., Hodgson, M., Lamson, G., Martin, H., Profitt, A., and Office of Occupational Health Nursing, Occupational Safety and Health Administration (OSHA), 2014. Heat illness and death among workers - United States, 2012-2013. MMWR. Morb. Mortal. Wkly. Rep. 63(31): 661-665.

Armstrong, L.E., Casa, D.J., Millard-Stafford, M., Moran, D.S., Pyne, S.W., and Roberts, W.O. 2007. American College of Sports Medicine position stand: exertional heat illness during training and competition. Med. Sci. Sports Exerc. 39(3): 556-572.

Armstrong, L.E., and Maresh, C.M. 1991. The induction and decay of heat acclimatisation in trained athletes. Sports. Med. 12(5): 302-312.

Arndt, V., Rothenbacher, D., Daniel, U., Zschenderlein, B., Schuberth, S., and Brenner, H. 2005. Construction work and occupational disability: a ten year follow-up of 14,474 male workers. Occup. Environ. Med. 62(8): 559-566.

Arvidsson, I., Balogh, I., Hansson, GÅ., Ohlsson, K., Åkesson, I., and Nordander, C. 2012. Rationalization in meat cutting - Consequences on physical workload. Appl. Ergon. 43(6): 1026-1032.

Aschoff, J. 1983. Circadian control of body temperature. J. Therm. Biol. 8(1-2): 143-147.

Åstrand, I. 1988. Physical demands in worklife. Scand. J. Work Environ. Health. 14(1): 10-13. Bai, L., Ding, G., Gu, S., Bi, P., Su, B., Qin, D., Xu, G., and Liu, Q. 2014. The effects of summer temperature and heat waves on heat-related illness in a coastal city of china, 2011-2013. Environ. Res. 132: 212-219. 
Baldus, S., Kluth, K., and Strasser, H. 2012. Order picking in deep cold - physiological responses of younger and older females. Part 2: body core temperature and skin surface temperature. Work. 41 Suppl 1: 3010-3017.

Bell, D.G., Tikuisis, P., and Jacobs, I. 1992. Relative intensity of muscular contraction during shivering. J. Appl. Physiol. 72(6): 2336-2342.

Berko, J., Ingram, D.D., Saha, S., and Parker, J.D. 2014. Deaths attributed to heat, cold, and other weather events in the united states, 2006-2010. Natl. Health. Stat. Report. 1-15.

Blacker, S.D., Wilkinson, D.M., and Rayson, M.P. 2009. Gender differences in the physical demands of British Army recruit training. Mil. Med. 174(8): 811-816.

Bortkiewizc, A., Gadzicka, E., Szymczak, W., Styjkowska, A., Koszada-Wlodarczyk, W., and Makowiec-Dabrowska, T. 2006. Physiological reaction to work in cold microclimate. Int. J. Occup. Med. Environ. Health. 19(2): 123-131.

Brake, D.J., and Bates, G.P. 2000. Occupational heat illness: an intervention study. In Proceedings of the International Conference on Physiological and Cognitive Performance in Extreme Environments. Defence Science and Technology Organisation, Australian Department of Defence, Canberrra. pp. 170-172.

Brake, D.J., and Bates, G.P., 2003. Fluid losses and hydration status of industrial workers under thermal stress working extended shifts. Occup. Environ. Med. 60(2): 90-96.

Brake, R., and Fulker, B. 2000. The ventilation and refrigeration design for Australia;s deepest and hottest underground operation - enterprise mine. In Proceedings of the MasMin. The Australasian Institute of Mining and Metallurgy, Brisbane, Australia. pp. 611-621. 
Brake, R., Donoghue, M., and Bates, G. 1998. A new generation of health and safety protocols for working in heat. In Queensland Mining Industry Health and Safety Conference Proceedings. pp. 91-100.

Bruce, R.A., Blackmon, F.R., Jones, J.W., and Strait, G. 1963. Exercising testing in adult normal subjects and cardiac patients. Pediatrics 32(4): 742-756.

Buckle, P., and Devereaux, J. 1999. Work related neck and upper limb disorders: report of European Agency for Safety and Health at Work. Luxembourg: Office for Official Publications of the European Communities.

Budd, G.M. 2008. Wet-bulb globe temperature (WBGT) - its history and its limitations. J. Sci. Med. Sport. 11(1): 20-32.

Buzanello, M.R., and Moro, A.R. 2012. Slaughterhouse workers exposed to cold: proposal of reference thermography values for hands. Work. 41(suppl 1): 2876-2871.

Campbell, D. 1999. Health hazards in the meatpacking industry. Occup. Med. 14(2): 351-372.

Carlsen, K.H. 2012. Sports in extreme conditions: The impact of exercise in cold temperatures on asthma and bronchial hyper-responsiveness in athletes. Br. J. Sports. Med. 46(11): 796-799.

Carlsson, I.K., and Dahlin, L.B. 2014. Self-reported cold sensitivity in patients with traumatic hand injuries or hand-arm vibration syndrome - an eight year follow up. BMC. Musculoskelet. Disord. 15: 83.

Carter III, R., Cheuvront, N., Williams, J.O., Kolka, M.A., Stephenson, L.A., Sawka, M.N., and Amoroso, P.J. 2005. Epidemiology of hospitalizations and deaths from heat illness in soldiers. Med. Sci. Sports Exerc. 37(8): 1338-1344. 
Chen, F., Li, T., Huang, H., and Holmer, I. 1991. A field study of cold effects among cold store workers in China. Arct. Med Res. 50 Suppl 6: 99-103.

Cheung, S.S., and Daanen, H.A.M. 2012. Dynamic adaptation of the peripheral circulation to cold exposure. Microcirculation. 19(1): 65-77.

Cheung, S.S., Montie, D.L., White, M.D., and Behm, D. 2003. Changes in manual dexterity following short-term hand and forearm immersion in $10^{\circ} \mathrm{C}$ water. Aviat. Space Environ. Med. 74(9): 990-993.

Cheung, S.S., and McLellan, T.M. 1998a. Influence of hydration status and fluid replacement on heat tolerance while wearing NBC protective clothing. Eur. J. Appl. Physiol. 77: 139-148.

Cheung, S.S., and McLellan, T.M. 1998b. Heat acclimation, aerobic fitness, and hydration effects on tolerance to uncompensable heat stress. J. Appl. Physiol. 84(5): 1731-1739.

Christensen, H., Sogaard, K., Pilegaard, M., and Olsen, H.B. 2000. The importance of work/rest pattern as a risk factor in repetitive monotonous work. Int. J. Ind. Ergon. 25(4): 367-373. Chung N.K., and Pin C.H. 1996. Obesity and the occurrence of heat disorders. Mil. Med. 161(12): 739-742.

Chung, Y., Lim, Y.-H., Honda, Y., Guo, Y.-L.L., Hashizume, M., Bell, M.L., Chen, B.-Y., and Kim, H. 2015. Mortality related to extreme temperature for 15 cities in northeast Asia. Epidemiology. 26(2): 255-262.

Cotter, J., Thornton, S., Lee, J.K.W. and Laursen, P. 2014. Are we being drowned in hydration advice? Thirsty for more?. Extreme Physiol. \& Med, 29(3): 18.

Cowell, S.A., Stocks, J.M., Evans, D.G., Simonson, S.R., and Greenleaf, J.E. 2002. The exercise and environmental physiology of extravehicular activity. Aviat. Space. Environ. Med. 73(1): 54-67. 
Cross, R.B., Galton-Fenzi, B., and Jordan, L. 1989. A simple field test for assessing salt balance in heat-stressed miners. J. Occup. Med. 31(8): 668-673.

Daanen, H.A., van de Vliert, E., and Huang, X. 2003. Driving performance in cold, warm, and thermoneutral environments. Appl. Ergon. 34(6): 597-602.

DeGroot, D.W., Gallimore, R.P., Thompson, S.M., and Kenefick, R.W. 2013. Extremity cooling for heat stress mitigation in military and occupational settings. J. Therm. Biol. 38(6): 305-310.

Domitrovich, J.W., Cuddy, J.S., and Ruby, B.C. 2010. Core temperature sensor ingestion timing and measurement variability. J Athl Train. 45(6): 594-600

Dovrat, E., and Katz-Leurer, M. 2007. Cold exposure and low back pain in store workers in Israel. Am. J. Ind. Med. 50(8): 626-631.

Dunne, J.P., Stouffer, R.J., and John, J.G. 2013. Reductions in labour capacity from heat stress under climate warming. Nat. Climate Change. 3: 563-566.

Druyan, A., Makranz, C., Moran, D., Yanovich, R., Epstein, Y., and Heled Y. 2012. Heat tolerance in women - reconsidering the criteria. Aviat. Space. Environ. Med. 83(1): 5860.

Epstein, Y., and Heled, Y. 2013. Back to play of athletes after exertional heat stroke. Curr. Sports Med. Rep. 12(5): 346.

Fallowfield, J., Blacker, S., Willems, M., Davey, T., and Layden, T. 2012. Neuromuscular and cardiovascular responses of Royal Marine recruits to load carriage in the field. Appl. Ergon. 43(6): 1131-1137.

Flouris, A.D., Westwood, D.A., and Cheung, S.S. 2007. Thermal balance effects on vigilance during 2-hour exposures to $-20^{\circ} \mathrm{C}$. Aviat. Space. Environ. Med. 78: 673-679. 
Fortune, M., Mustard, C., and Brown, P. 2014. The use of bayesian inference to inform the surveillance of temperature-related occupational morbidity in Ontario, Canada, 20042010. Environ. Res. 132: 449-456.

Fortune ,M.K., Mustard, C.A., Etches, J.J.C., and Chambers, A.G. 2013. Work-attributed illness arising from excess heat exposure in Ontario, 2004-2010. Can. J. Public. Health. 104(5): e420-e426.

Fouillet, A., Rey, G., Laurent, F., Pavillon, G., Bellec, S., Guihenneuc-Jouyaux, C., Clavel, J., Jougla, E., and Hémon, D. 2006. Excess mortality related to the August 2003 heat wave in France. Int. Arch. Occup. Environ. Health. 80(1): 16-24.

Friedl, C.K. 2007. Physiological monitoring of the warfighter. J Diabetes Sci Technol. 1(1): 116.

Gabriel, K.M.A., and Endlicher, W.R. 2011. Urban and rural mortality rates during heat waves in Berlin and Brandenburg, Germany. Environ. Pollut. 159(8-9): 2044-2050.

Galloway, S.D.R., and Maughan, R.J. 1997.Effects of ambient temperature on the capacity to perform prolonged cycling exercise in man. Med. Sci. Sports. Exerc. 29(9): 1240-1249.

Genaidy, A.M., Delgado, E., and Bustos, T. 1995. Active microbreak effects on musculoskeletal comfort ratings in meatpacking plant. Ergonomics. 38(2): 326-336.

Geng, Q., Holmer, I., Hartog, D.E., Havenith, G., Jay O., Malchaire, J., Piette, A., Rintamaki, H., and Rissanen, S. 2006. Temperature limit values for touching cold surfaces with the fingertip. Ann. Occup. Hyg. 50(8): 851-862.

Grenier, J., Guillaume, M., Peyrot, N., Samozino, P., Oullion, R., Messonnier, L., and Morin, JB. 2012. Effects of extreme-duration heavy load carriage on neuromuscular function and locomotion: A military based study. PLOS One. 7(8): e43586. 
Gubernot, D.M., Anderson, G.B., and Hunting, K.L. 2014. The epidemiology of occupational heat exposure in the united states: A review of the literature and assessment of research needs in a changing climate. Int. J. Biometeorol. 58(8): 1779-1788.

Guo, Y., Gasparrini, A., Armstrong, B., Li S., Tawatsupa, B., Tobias, A., Lavigne, E., de Sousa Zanotti Stagliorio Coelho, M., Leone, M., Pan, X., Tong, S., Tian, L., Kim, H., Hashizume, M., Honda, Y., Guo, Y.-L.L., Wu, C.-F., Punnasiri, K., Yi, S.-M., Michelozzi, P., Saldiva, P.H.N., and Williams, G. 2014. Global variation in the effects of ambient temperature on mortality. Epidemiology. 25(6): 781-789.

Hamlet, M.P. 1988. Human cold injuries. In Human Performance Physiology and Environmental Medicine in Terrestrial Extremes. Edited by K.B. Pandolf, M.N. Sawka and R.R Gonzalez. Benchmark Press, Indianapolis. pp. 435-466.

Hancock, P.A., Ross, J.M., and Szalma, J.L. 2007. A meta-analysis of performance response under thermal stressors. Human. Factors. 49(5): 851-877.

Harbin G., and Olson J. 2005. Post-offer, pre-placement testing in industry. Am. J. Ind. Med. 47(4): 296-307.

Harman, E.A., Gutekunst, D.J., Frykman, P.N., Nindl, B.C., Alemany, J.A., Mello, R.P., and Sharp, M.A. 2008. Effects of two different eight-week training programs on military physical performance. J. Strength. Cond. Res. 22(2): 524-534.

Hartmann, B., and Fleischer, A.G. 2005. Physical load exposure at construction sites. Scand. J. Work Environ. Health. 31(2): 88-95.

Hartung, G.H., Myhre, L.G., and Nunneley, S.A. 1980. Physiological effects of cold air inhalation during exercise. Aviat. Space Environ. Med. 51(6): 591-594. 
Havenith, G., and van Middendorp, H. 1990. The relative influence of physical fitness, acclimatization state, anthropometric measures and gender on individual reactions to heat stress. Eur. J. Appl. Occup. Physiol. 61(5-6): 419-427.

Havenith, G., Inoue, Y., Luttikholt, V., and Kenney, W.L. 1995a. Age predicts cardiovascular, but not thermoregulatory, responses to humid heat stress. Eur. J. Appl. Occup. Physiol. 70(1): 88-96.

Havenith, G., Luttikholt, V.G., and Vrijkotte, T.G. 1995b. The relative influence of body characteristics on humid heat stress response. Eur. J. Appl. Physiol. Occup. Physiol. 70(3): 270-279.

Henschel, A. 1971. The environment and performance. In Physiology of work capacity and fatigue. Edited by E. Simonson. Springfield. Charles C Thomas Publisher, Illinois, USA. pp. 345.

Heus, R., Daanen, H.A., and Havenith, G. 1995. Physiological criteria for functioning of hands in the cold: A review. Appl. Ergon. 26(1): 5-13.

Hew-butler, T., Rosner, M.H., Fowkes-Godek, S., Dugas, J.P., Hoffman, M.D., Lewis, D.P., Maughan, R.J., Miller, K.C., Montain, S.J., Rehrer, N.J., Roberts, W.O., Rogers, I.R., Siegel, A.J., Stuempfle, K.J., WInger, J.M., and Verbalis, J.G. 2015. Statement of the third international exercise-associated hyponatremia consensus development conference, Carlsbad, California, 2015. Clin J Sport Med. 25(4): 303-320. 
House, J.R., Holmes, C., and Allsopp, A.J. 1997. Prevention of heat strain by immersing the hands and forearms in water. J. R. Nav. Med. Serv. 83(1): 26-30.

House J.R., Lunt, H., Magness, A., and Lyons, J. 2003. Testing the effectiveness of techniques for reducing heat strain in Royal Navy nuclear, biological and chemical cleansing stations' teams. J. R. Nav. Med. Serv. 89(1): 27-34.

Huang, C., Barnett, A.G., Wang, X., Vaneckova, P., FitzGerald, G., and Tong, S. 2011. Projecting future heat-related mortality under climate change scenarios: A systematic review. Environ. Health. Perspect. 119(12): 1681-1690.

Hyatt, O.M., Lemke, B., and Kjellstrom, T. 2010. Regional maps of occupational heat exposure: Past, present, and potential future. Glob. Health. Action. 3: 5715.

Ilmarinen, J. 1992. Job design for the aged with regard to the decline in their maximal aerobic capacity: Part I - Guidelines for the practitioner. Int. J. Ind. Ergon. 10(1-2): 53-63.

Ilmarinen J. 2001. Aging workers. Occup. Environ. Med. 58(8): 546-552.

Imray, C.H.E., and Oakley, E. 2005. Cold still kills: cold-related illnesses in military practice freezing and non-freezing cold injury. J. R. Army. Med. Corps. 151(4): 218-222.

Imray, C.H., Richards, P., Greeves, J., and Castellani, J.W. 2011. Nonfreezing cold-induced injuries. Journal. of. the. Royal Army Med. Corps. 157(1): 79-84.

Inoue, Y., Tanaka, Y., Omori, K., Kuwahara, T., Ogura, Y., and Ueda, H. Sex- and menstrual cycle-related differences in sweating and cutaneous blood flow in response to passive heat exposure. Eur J Appl Physiol. 94(3): 323-32.

International Association for Fire Fighters (IAFF). 2006. Thermal heat stress protocol for firefighters and hazmat responders. Available from http://www. 
Iaff.org.hs/EIRP/files/Rehab\%20SOP\%20Examples/Misc\%20Rehab\%20SOPs\%20and\% 20Procedures/IAFF\%20Thermal\%20Stress\%20Protocol.doc.

ISO 7243. 1989. Hot environments - estimation of the heat stress on working man based on WBGT index (pp. ISO7243 (Geneva: ISO)).

Jackson A.S. 1994. Preemployment physical evaluation. Exerc. Sport Sci. Rev. 22: 53-90.

Jamnik, V., Gumienak, R., and Gledhill, N. 2013. Developing legally defensible physiological employment standards for prominent physically demanding public safety occupations: a Canadian perspective. Eur. J. Appl. Physiol. 113: 2447-2457.

Japan Society for Occupational Health. 2005. Recommendation of occupational exposure limits 2005-2006. J. Occup. Health 47: 354-370.

Jay, O., and Kenny, G.P. 2010. Heat exposure in the Canadian workplace. Am. J. Ind. Med. 53: 842-853.

Jebens, E., Mamen, A., Medbo, J.I., Knudsen, O. and Veiersted, K.B. 2015. Are elderly construction workers sufficiently fit for heavy manual labour? Ergonomics. 58(3): 450462.

Jelewska, M., Grubman-Novak, M., Leszczylska, I., and Jaremin, B. 2012. Occupational hazards for fishermen in the workplace in Polish coastal and beach fishing - a point of view. Int. Marit. Health. 63(1): 40-48.

Johnson, E.C., Kolkhorst, F.W., Richburg, A., Schmitz, A., Martinez, J., and Armstrong, L.E. 2013. Specific exercise heat stress protocol or a triathlete's return from exertional heat stroke. Curr. Sports Med. Rep. 12(2): 106-106. 
Johnson, J.M., Minson, C.T., and Kellogg, D.L. 2014. Cutaneous vasodilator and vasoconstrictor mechanisms in temperature regulation. Compr. Physiol. 4(1): 33-89.

Kaciuba-Uscilko, H., and Grucza, R. 2001. Gender differences in thermoregulation. Curr. Opin. Clin. Nutr. Metab. Care. 4(6): 533-536.

Kazman, J.B., Heled, Y., Lisman, P.J., Druyan, A., Deuster, P.A., and O’Connor, F.G. 2013. Exertional heat illness: the role of heat tolerance testing. Curr. Sports Med. Rep. 12(2): 101-105.

Keim, S., Guisto, J., and Sullivan, J. 2002. Environmental thermal stress. Ann. Agric. Environ. Med. 9(1): 1-15.

Kenny, G.P., Yardley, J., Brown, C., Sigal, R.J., and Jay, O. 2010. Heat stress in older individuals and patients with common chronic diseases. CMAJ: Canadian Medical Association Journal. 182(10): 1053-1060.

Kenny, G.P., Yardley, J., Martineau, L. and Jay, O. 2008. Physical work capacity in older adults: implications for the aging worker. Am. J. Ind. Med. 51: 610-625.

Kielblock, J. 1992. Heat stress management: an industrial perspective. In Proceedings of the fifth international conference on environmental ergonomics. Chamber of Mines of South Africa, Johannesburg, Republic of South Africa. pp. 100-101.

Kiparski, R., and Massmann, W. 1982. Die Beuerteilung von physischer und psychischer Beanspruchung beim Besteigen von hohen Masten anhand physiologischer Parameter. Int. Arch. Occup. Environ Health. 50: 237-244.

Kjellstrom, T., and Weaver, H.J. 2009. Climate change and health: Impacts, vulnerability, adaptation and mitigation. New South Wales Public Health Bulletin. 20: 5-9. 
Kjellstrom, T., Holmer, I., and Lemke, B. 2009. Workplace heat stress, health and productivity an increasing challenge for low and middle-income countries during climate change. Glob. Health Action. 2: doi:10.3402/gha.v2i0.2047.

Kjellstrom, T., Lemke, B., and Otto, M. 2013. Mapping occupational heat exposure and effects in south-east Asia: Ongoing time trends 1980-2011 and future estimates to 2050. Ind. Health. 51: 56-67.

Klimmer, F., Kylian, H., Linke, G., Maxeiner, B., Heinrich, V., Merdian, K., and Rutenfranz, J. 1990. Belastung und beanspruchung des Kranfuhrers beim Aufstieg zur Kranfuhrskabine verschiedener Turmdrehkrantypen. Arbeitsmed. Sozialmed. Präventivmed. 25: 356-361.

Kluth, K., Baldus, S., and Strasser, H. 2012. Order picking in deep cold - physiological responses of younger and older females. Part 1: heart rate. Work. 41 Suppl 1: 3002-3009.

Knapik, J.J., Rieger, W., Palkoska, F., Van Camp, S., and Darakjy, S. 2012. United States Army physical readiness training: rationale and evaluation of the physical training doctrine. J. Strength. Cond. Res. 23(4): 1353-1362.

Kräuchi, K. and Wirz-Justice, A. 1994. Circadian rhythm of heat production, heart rate, and skin and core temperature under unmasking conditions in men. Am. J. Physiol. 167(3 Pt 2): R819-R829.

Kukkonen, K. 1982. Physical fitness and cardiovascular risk factors in the middle-aged. Publications of the University of Kuopio. Medicine 5/1982.

Launay, J.C., and Savourey, G. 2009. Cold adaptations. Ind. Health. 47(3): 221-227.

LaVoy, E.C., McFarlin, B.K., and Simpson, R.J. 2011. Immune responses to exercising in a cold environment. Wilderness. Environ. Med. 22(4): 343-351. 
Lee, J.K.W., Ang, W.H., Nio, A.Q.X, Johnson C, Aziz, A. R. Lim, C.L. and Hew-Butler T. 2011. First cases of exercise-associated hyponatremia in Asia. Int J. Sports Med. 32(4): 297302.

Lee, J.K.W., Nio, A.Q.X., Fun, D.C.Y., Teo, Y.S., Chia, E.V. and Lim, C.L. 2012. Standard heat acclimatisation enhances overall work tolerance with minimal effects on thermoregulation in tropical native soldiers. J. Therm. Biol. 37: 366-373.

Lee, J.K.W, Yeo, Z.W., Nio, A.Q., Koh, A.C., Teo, Y.S., Goh, L.F., Tan, P.M., and Bryne, C. 2013. Cold drink attenuates heat strain during work-rest cycles. Int. J. Sports Med. 34(12): 1037-1042.

Leveritt, S. 1998. Heat stress in mining. Work-safe Australia Ergonomics Review. Available from http://www.ergonomics.org.au/downloads/EA_Journals/Heat_Stress_in_Mining__leveritt.pdf.

Lim, C.L., and Song, E. 2000. Heat strain monitoring and physical exertion. Defence Medical Research Institute.

Lin, M.T., Liu, H.H., and Yang, Y.L. 1997. Involvement of interleukin-1 receptor mechanisms in development of arterial hypotension in rat heatstroke. Am J Physiol. 273(4): H2072-2077.

Lipscomb, H.J., Epling, C.A., Pompeii, L.A., and Dement, J.M. 2007. Musculoskeletal symptoms among poultry processing workers and a community comparison group: Black women in low wage jobs in the rural south. Am. J. Ind. Med. 50(5): 327-338.

Lisman, P., Kazman, J.B., O’Connor, F.G., Heled, Y., and Deuster, P.A. 2014. Heat tolerance testing: association between heat intolerance and anthropometric and fitness measurements. Mil. Med. 179(11): 1339-1346.

Lord, C., Netto, K., Petersen, A., Nichols, D., Drain, J., Philips, M., and Aisbett, B. 2012. 
Validating 'fit for duty' tests for Australian volunteer fire fighters suppressing bushfires. Appl Ergon. 43(1): 191-197.

Lucas, R.A.I., Epstein, Y., and Kjellstrom, T. 2014. Excessive occupational heat exposure: A significant ergonomic challenge and health risk for current and future workers. Extrem. Physiol. Med. 3: 14.

Lundgren, K., Kuklane, K., Gao, C., and Holmér, I. 2013. Effects of heat stress on working populations when facing climate change. Ind. Health. 51(1): 3-15.

Makinen, T.M., and Hassi, J. 2009. Health problems in cold work. Ind. Health. 47: 207-220.

Makinen, T.M., Rintamaki, H., Korpelainen, J.T., Kampman, V., Paakkonen, T., Oksa, J., Palinkas, L.A., Leppaluoto, J., and Hassi, J. 2005. Postural sway during single and repeated cold exposures. Aviat. Space Environ. Med. 76(10): 947-953.

Malmberg, J. (Ed.) 2011. Physical fitness tests in the Nordic Armed Forces - A description of the basic test protocols. The Norwegian Defence University College, Norwegian School of Sports Sciences/Defence Institute, Oslo. ISSN 1891-8751.

Matheson, C., Morrison, S., Murphy, E., Lawrie, T., Ritchie, L., Bond, C. 2010. The health of the fishermen in the catching sector of the fishing industry: a gap analysis. Occup. Med. 51(5): $305-311$.

McDermott, B.P., Casa, D.J., Yeargin, S.W., Ganio, M.S., Armstrong, L.E., and Maresh, C.M. 2007. Recovery and return to activity following exertional heat stroke: considerations for the sports medicine staff. J. Sport Rehab. 16(3): 163-181.

McGorry, R., Dempsey, P., and O’Brien, N. 2004. The effect of workstation and task variables on forces applied during simulated meat cutting. Appl. Ergon. 18: 233-237. 
McLellan, T.M. 1998. Sex-related differences in thermoregulatory responses while wearing protective clothing. Eur. J. Appl. Physiol. Occup. Physiol. 78(1): 28-37.

McLellan, T.M., Cheung, S.S., Latzka, W.A., Sawka, M.N., Pandolf, .K.B, Millard, C.E., and Withey, W.R. 1999. Effects of dehydration, hypohydration, and hyperhydration on tolerance during uncompensable heat stress. Can J Appl Physiol. 24(4): 349-361.

McLellan, T.M., Daanen, H.A.M., and Cheung, S.S. 2013. Encapsulated environment. Compr. Physiol. 3(3): 1363-1391.

McPherson, M.J. 2011. Physiological reactions to climatic conditions. In: Subsurface ventilation Engineering. Available from https://www.mvsengineering.com/files/SubsurfaceBook/MVS-SVE_Chapter17.pdf.

Ministry of Defence. 2012. Climatic illness and injury in the armed forces: force protection and initial medical treatment. JSP 539. Headquarters, Surgeon General. DMS Whittington, Whittington Barracks, Lichfield, UK.

Montain, SJ., and Coyle, E.F. 1992. Influence of graded dehydration on hyperthermia and cardiovascular drift during exercise. J Appl Physiol. 73(4): 1340-50.

Moran, D.S., Heled, Y., Still, L., and Shapiro Y. 2004. Assessment of heat tolerance for post exertional heat stroke individuals. Med. Sci. Monit. 10(6): CR252-257.

Moran, D.S., Erlich, T., and Epstein, Y. 2007. The heat tolerance test: an efficient screening tool for evaluating susceptibility to heat. J. Sport. Rehabil. 16(3): 215-221.

Mourtzoukou, E.G., and Falagas, M.E. 2007. Exposure to cold and respiratory tract infections. Int. J. Tuberc. Lung. Dis. 11(9): 938-943.

National Institute for Occupational Safety and Health. 2013. Criteria for a recommended standard: occupational exposure to heat and hot environments. Cincinnati, OH: NIOSH. 
Nielsen, B. 1998. Heat acclimation - mechanisms of adaptation to exercise in the heat. Int. J. Sports Med. 19: S154-S156.

Nordander, C., Ohlsso, K., Balogh, I., Rylander, L., Pålsson, B., and Skerfving, S. 1999. Fish processing work: the effect of two sex dependent exposure profiles on musculoskeletal health. Occup. Environ. Med. 56: 256-264.

O’Brien, C., Hoyt, R.W., Buller, M.J., Castellani, J.W., and Young, A.J. 1998. Telemetry pillmeasurement of core temperature in humans during active heating and cooling. Med Sci Sports Exer. 30(3): 468-472.

O’Connor, F.G., Williams, A.D., Blivin, S., Heled, Y., Deuster, P., and Flinn, S.D. 2007. Guidelines for return to duty (play) after heat illness: a military perspective. J. Sport Rehabil. 16(3): 227-237.

O’Connor, F.G., Casa, D.J., Bergeron, M.F., Carter, R., Deuster, P., Heled, Y., Kark, J., Leon, L., McDermott, B., O’Brien, K., Roberts, W.O., and Sawka, M. 2010. American college of sports medicine roundtable on exertional heat stroke - return to duty/return to play: conference proceedings. Curr. Sports Med. Rep. 9(5): 314-321.

Occupational health care act. (1383/2001).

Occupational safety act. (738/2002).

Oksa, J., Ducharme, M., and Rintamäki, H. 2002. Combined effect of repetitive work and cold on muscle function and fatigue. J. Appl. Physiol. 92: 354-361.

Oksa, J., Kaikkonen, H., Sorvisto, P., Vaappo, M., Martikkala, M., and Rintamäki, H. 2004. Changes in maximal cardiorespiratory capacity and submaximal strain while exercising in cold. J. Therm. Biol. 29: 815-818. 
Oksa, J., Sormunen, E., Koivukangas, U., Rissanen, S., and Rintamäki, H. 2006a. Changes in neuromuscular function due to intermittently increased workload during repetitive work in cold conditions. Scand J Work Environ Health 32: 300-309.

Oksa, J., Rintamäki, H., and Mäkinen, T. 2006b. The effect of training of military skills on performance in cold environment. Mil. Med. 171(8): 757-761.

Oksa, J., Peura, S., Mäkinen, T., Lindholm, H., Rintamäki, H., Rissanen, S., Latvala, J., Vaara, K., and Oksa, P. 2011. Physical test recommendations for work at height. Technical report, ISBN 978-952-261-115-4. (In Finnish).

Oksa, J., Paasovaara, S., and Ollila, T. 2012. Intermittently increased repetitive work intensity and neuromuscular function in cold. Ind. Health. 50(4): 307-315.

Oksa, J., Hosio, S., Mäkinen, T., Lindholm, H., Rintamäki, H., Rissanen, S., Latvala, J., Vaara, K., and Oksa, P. 2014. Muscular, cardiorespiratory and thermal strain of mast and pole workers. Ergonomics. Mar 24, PMID: 24655301.

Oliveira, V., Gaspar, A., Andre, J., and Quintela, D. 2014. Subjective analysis of cold thermal environments. Appl. Ergon. 45(3): 534-543.

Parkhouse, W., and Gall, B. 2004. Task frequency as a function of age for the powerline technician trade. Ergonomics. 15: 660-670.

Parsons, K.C. 1993. Human Thermal Environments. Taylor \& Francis, London. pp. 359.

Patterson, M.J., Roberts, W.S., Lau, W.M., and Prigg, S.K. 2005. Gender and physical training effects on soldier physical competencies and physiological strain. DSTO-TR-1875. Human Protection and Performance Division, Defence Science and Technology Organisation, Melbourne, Victoria, Australia. 
Percin, F., Akyol, O., Davas, A., and Saygi, H. 2012. Occupational health of Turkish Aegean small-scale fishermen. Occup. Med. 62(1): 148-151.

Perkiö-Mäkelä, M. 1999. Influence of exercise-focused group activities on the physical activity, functional capacity, and work ability of female farmers-A three year follow-up. Int. J. Occup. Safe. Ergon. 5(3): 381-394.

Pienimäki, T. 2000. Cold exposure and musculoskeletal disorders and diseases. Int. J. Circump. Health. 61: 173-182.

Pienimäki, T. 2002. Cold exposure and musculoskeletal disorders and diseases. A review. Int. J. Circumpolar. Health. 61(2): 173-182.

Pienimäki, T., Karppinen, J., Rintamäki, H., Borodulin, K., Laatikainen, T., Jousilahti, P., Hassi, J., and Näyhä, S. 2014. Prevalence of cold-related musculoskeletal pain according to selfreported threshold temperature among the finnish adult population. Eur. J. Pain. 18(2): 288-298.

Pilcher, J.J., Nadler, E., and Busch, C. 2002. Effects of hot and cold temperature exposure on performance: A meta-analytic review. Ergonomics. 45(10): 682-698.

Quinn, A., Tamerius, J.D., Perzanowski, M., Jacobson, J.S., Goldstein, I., Acosta, L., and Shaman, J. 2014. Predicting indoor heat exposure risk during extreme heat events. Sci. Total. Environ. 490: 686-693.

Ramsey, J.D. 1975. Heat stress standard: OSHA's advisory committee recommendations. Natl. Saf. News. 89-95.

Raymond, L.W. 2014. Physiologic strain during treadmill electrocardiography in the medical evaluation of candidates for hazardous materials duty, with and without added heat stress. Emerg. Med. 4(6): 224. doi: 10.4172/2165-7548.1000224. 
Reilly, T., Wooler, A., and Tipton, M. 2006. Occupational fitness standards for beach lifeguards. Phase 1: the physiological demands of beach lifequarding. Occup. Med. 56(1): 6-11.

Reilly, T., Wooler, A., and Tipton, M. 2006. Occupational fitness standards for beach lifeguards. Phase 2: the development of easily administered fitness test. Occup. Med. 56(1): 12-17. Research and Technology Organisation, 2010. Real-time physiological and psycho-physiological status monitoring. RTO technical report, TR-HFM-132. Research and Technology Organisation, North Atlantic Treaty Organisation, Neuilly-sur-Seine, France.

Rey, G., Jougla, E., Fouillet, A., Pavillon G., Bessemoulin, P., Frayssinet, P., Clavel, J., and Hemon, D. 2007. The impact of major heat waves on all-cause and cause-specific mortality in France from 1971 to 2003. Int. Arch. Occup. Environ. Health. 80(7): 615626.

Richmond, V.L., Carter, J.M., Wilkinson, D.M., Horner, F.E., Rayson, M.P., Wright, A., and Bilzon, J.L. 2012. Comparison of the physical demands of single-sex training for male and female recruits in the British Army. Mil. Med. 177(6): 709-715.

Richmond, V.L., Horner, F.E., Wilkinson, D.M., Rayson, M.P., Wright, A. and Izard, R. 2014. Energy balance and physical demands during an 8-week arduous military training course. Mil. Med. 179(4): 421-427.

Rintamäki, H., and Rissanen, S. 2006. Heat strain in cold. Ind. Health. 44(3): 427-432.

Rintamäki, H., Rissanen, S., Mäkinen, T., and Peitso, A. 2004. Finger temperatures during military field training at 0 to $-29{ }^{\circ} \mathrm{C}$. J. Therm. Biol. 29(7-8): 857-860.

Roberts, S. 2010. Britain's most hazardous occupation: Commercial fishing. Acc. Anal. Prev. 42(1): 44-49. 
Rodahl, K., and Vokac, Z. 1977. Work stress in long line bank fishing. Scand. J. Work Environ. Health. 3(3): 154-159.

Rodahl, K., and Vokac, Z. 1979. The work physiology of fishing. Psychother. Psychohom. 32(14): $52-59$.

Rodahl, K., Vokac, Z., Fugelli, P., Vaage, O., and Matheum, S. 1974. Circulatory strain, estimated energy output and catecholamine excretion in Norwegian coastal fishermen. Ergonomics. 17(5): 585 .

Rodgers, S.H. 1988. Job evaluation in worker fitness determination. Occup. Med. 3(2): 219-239.

Rosenblum K.E., and Shankar A. 2006. A study of the effects of isokinetic pre-employment physical capability screening in the reduction of musculoskeletal disorders in a labor intensive work environment. Work. 26(2): 215-228.

Rowell, L.B. 1993. Central circulatory adjustments to cardiovascular exercise. Human Cardiovascular Control. Oxford University Press, New York. pp. 162-203.

Sawka, M.N., Young, A.J,, Francesconi, R.P., Muza, S.R., and Pandolf, K.B. 1985. Thermoregulatory and blood responses during exercise at graded hypohydration levels. J Appl Physiol. 59(5): 1394-401.

Sawka, M.A., Young A.J., Latzka, W.A., Neufer, P.D., Quigley, M.D., and Pandolf, K.B. 1992. Human tolerance to heat strain during exercise: influence of hydration. J Appl Physiol. 73(1): $368-75$

Schmeltz, M.T., Sembajwe, G., Marcotullio, P.J., Grassman, J.A., Himmelstein, D.U., and Woolhandler, S. 2015. Identifying individual risk factors and documenting the pattern of heat-related illness through analyses of hospitalization and patterns of household cooling. PLoS One. 10(3): e0118958. 
Schulte, P.A., and Chun, H. 2009. Climate change and occupational safety and health: Establishing a preliminary framework. J. Occup. Environ. Hyg. 6(9): 542-554.

Schutte, P. 2010. Heat Stress Management in Hot Mines. In Extracting the Science: A Century of Mining Research. Edited by J.F. Brune. Society for Mining, Metallurgy, and Exploration, Inc. Littleton, Colorado, USA. pp. 30-34.

Selkirk, G.A. and McLellan, T.M. 2001. Influence of aerobic fitness and body fatness on tolerance to uncompensable heat stress. J. Appl. Physiol. 91: 2055-2063.

Semenza, J.C., Rubin, C.H., Falter, K.H., Selanikio, J.D., Flanders, W.D., Howe, H.L., and Wilhelm, J.L. 1996. Heat-related deaths during the july 1995 heat wave in chicago. N. Engl. J. Med. 3352: 84-90.

Shapiro, Y., Magazanik, A., Udassin, R., Ben-Baruch, G., Shvartz, E., and Shoenfeld, Y. 1979. Heat intolerance in former heatstroke patients. Ann. Intern. Med. 90(6): 913-916.

Siddall, A.G., Standage, M., Stokes, K.A., and Bilzon, J.L.J. 2014. Development of occupational fitness standards for the UK Fire and Rescue Services (FRS). Department for Health, University of Bath, Bath, United Kingdom.

Singapore Armed Forces, 2010. Management of heat injuries. SAF-MOH Clinical Practice guidelines 1/2010. SAF Medical Corps, Singapore.

Sinks, T, Mathias, C.G., Halperin, W., Timbrook, C., Newman, S. 1987. Surveillance of work related cold injuries using workers' compensation claims. J. Occup. Med. 29(6): 504-509.

Skoldstrom B. 1987. Physiological responses of firefighters to workload and thermal stress. Ergonomics. 30(11): 1589-1597. 
Smith, D.L., Petruzzello, S.J., Kramer, J.M., and Misner, J.E. 1997. The effects of different thermal environments on the physiological and psychological responses of firefighter to a training drill. Ergonomics. 40(4): 500-510.

Sormunen, E., Oksa, J., Pienimäki, T., Rissanen, S., and Rintamäki, H. 2006. Muscular and cold strain of female workers in meatpacking work. Int. J. Ind. Ergon. 36(8): 713-720.

Sormunen, E., Rissanen, S., Oksa, J., Pienimäki, T., Remes, J., and Rintamäki, H. 2009. Muscular activity and thermal responses in men and women during repetitive work in cold conditions. Ergonomics. 52(8): 964-976.

Sovelius, R., Oksa, J., Rintala, H., Huhtala, H., and Siitonen, S. 2007. Ambient temperature and neck EMG with +Gz loading on a trampoline. Aviat. Space. Environ. Med. 78(6): 574578.

Sundell, J., and Ersson, C. 1981. Ventilation of work rooms. Department of Occupational Safety, General Bureau TAA 3, Collection of Reports AFS, Report No. 4: 9-11.

Sundstrup, E., Jakobsen, M., Andersen, C., Jay, K., Persson, R., Aagaard, P., and Andersen, L. 2014. Effect of two contrasting interventions on upper limb chronic pain and disability: A randomized controlled trial. Pain Physician. 17(2): 145-154.

Tan, P.M.S. and Lee, J.K.W. (2015). The role of fluid temperature and form on endurance performance in the heat. Scand J. Med Sci in Sports. (In press).

Taylor, N.A.S., Patterson, M.J., Regan, J.M., and Amos, D. 1997. Heat acclimation procedures: preparation for humid heat exposure. DSTO-TR-0580, Aeronautical and Maritime Research Laboratory, Defence Science and Technology Organisation, Melbourne, Victoria, Australia. 
Taylor, N.A., Machado-Moreira, C.A., van den Heuvel, A.M., and Caldwell J.N. 2014. Hands and feet: Physiological insulators, radiators and evaporators. Eur. J. Appl. Physiol. 114(10): 2037-2060.

Tharion, W.J, and Kaushik, S. 2006. Graphical user interface (GUI) for the Warfighter Physiological Status Monitoring (WPSM) system - U.S. Army Medic recommendations. USARIEM technical report T07-04. U.S. Army Research Institute of Environmental Medicine, Natick, MA.

Tipton, M., Milligan, G.S., and Reilly, T.J. 2013. Physiological employment standards I. Occupational fitness standards: objectively subjective? Eur. J. Appl. Physiol. 113(10): 2435-2446.

Tochihara, Y. 2005. Work in artificial cold environments. J. Physiol. Anthropol. 24(1): 73-76.

Tochihara, Y., Ohkubo, C., Uchiyama, I., and Komine, H. 1995. Physiological reaction and manual performance during work in cold storage. Appl. Human. Sci. 14(2): 73-77.

Tofari, P.J., Treloar, A.K.L., and Silk, A.J. 2013. A quantification of the physiological demands of the army emergency responder in the Australian army. Mil Med 178(5): 487-494.

Tseng, C.M., Chen, Y.T., Ou, S.M., Hsiao, Y.H., Li, S.Y., Wang, S.J., Yang, A.C., Chen, T.J., and Perng, D.W. 2013. The effect of cold temperature on increased exacerbation of chronic obstructive pulmonary disease: A nationwide study. PLoS. One. 8(3): e57066.

Turner, L.R., Barnett, A.G., Connell, D., and Tong, S. 2012. Ambient temperature and cardiorespiratory morbidity: A systematic review and meta-analysis. Epidemiology. 23(4): 594-606.

U.S. Army, 2003. Heat stress control and heat casualty management. TB MED 507/AFPAM 48152(1). Headquarters, Department of the Army and Air Force, Washington, DC. 
U.S. Department of Defense. 1980. Occupational and environmental health: Prevention, treatment and control of heat injuries. Headquarters, Departments of the Army, Navy and Air Force. TB MED 507, NAVMED P-5052-5, AFP 160-1.

Von Heimburg, E., Medbo, J.I., Sandsund, M., and Reinertsen, R.E. 2013. Performance on a work-simulating firefighter test versus approved laboratory tests for firefighters and applicants. Int. J. Saf. Ergon. 19(2): 227-43.

Von Heimburg, E., and Medbo, J.I. 2013. Energy cost of the Trondheim firefighter test for experienced firefighters. Int. J. Occup. Saf. Ergon. 19(2): 211-25. www.minehealth.eu

Wada, K., Yoshikawa, T., Hayashi, T., and Aizawa, Y. 2012. Emergency response technical work at Fukushima Dai-ichi nuclear power plant: occupational health challenges posed by the nuclear disaster. Occup. Environ. Med. 69: 599-602.

Wang, Z.Z., Wang, C.L., Wu, T.C., Pan,H.N., Wang, S.K., and Jiang, J.D. 2001. Autoantibody response to heat shock protein 70 in patients with heatstroke. Am J Med. 111(8): 654-657.

Williams, A.G. 2005. Effects of basic training in the British Army on regular and reserve army personnel. J. Strength Cond. Res. 19(2): 254-259.

Wyss, T., Scheffler, J., and Mäder, U. 2012. Ambulatory physical activity in Swiss Army recruits. Int. J. Sports. Med. 33(9): 716-722.

Xiang, J., Bi P., Pisaniello, D., and Hansen, A. 2014. Health impacts of workplace heat exposure: An epidemiological review. Ind. Health. 52(2): 91-101.

Yeo, Z.W., Fan, P.W.P., Nio, A.Q.X., Byrne, C. and Lee, J.K.W. 2012. Ice slurry on outdoor running performance in heat. Int. J. Sports Med. 33(11): 859-866. 
Yi W., and Chan A. 2014. Optimal work pattern for construction workers in hot weather: a case study in Hong Kong. J. Comput. Civ. Eng. doi: 10.1061/(ASCE)CP.1943-5487.0000419, 05014009.

Yip, F.Y., Flanders, W.D., Wolkin, A., Engelthaler, D., Humble, W., Neri, A., Lewis, L., Backer L., and Rubin C. 2008. The impact of excess heat events in Maricopa county, Arizona: 2000-2005. Int. J. Biometeorol. 52(8): 765-772. 
Table 1. Summary of current physical fitness tests in heat-related occupations that evaluate physical capacity to work in the heat.

\begin{tabular}{|c|c|c|c|c|}
\hline Occupation & Name and type of test & Population & Test description and details & Passing criteria \\
\hline \multirow[t]{4}{*}{ Mining } & $\begin{array}{l}\text { Medical and physical } \\
\text { examinations* }\end{array}$ & Applicants & $\begin{array}{l}\text { Screening of risk factors for heat } \\
\text { illness }\end{array}$ & $\begin{array}{l}\text { Medical } \\
\text { - No previous heat } \\
\text { disorders } \\
\text { Physical } \\
\text { - Age }<50 \text { yrs } \\
\text { - } \mathrm{BMI}<35 \\
\text { - } \text { Body mass }>50 \mathrm{~kg} \\
\text { - } \mathrm{VO}_{2 \max }>30 \mathrm{ml}^{-\mathrm{kg}^{-1}} \cdot \mathrm{min}^{-1}\end{array}$ \\
\hline & $\begin{array}{l}\text { Heat Tolerance } \\
\text { Screening (HTS) test* }\end{array}$ & Applicants & $\begin{array}{l}\text { Bench-stepping exercise in heat } \\
\text { chamber } \\
\text { - } 30 \text {-min at } 80 \mathrm{~W} \\
\text { - } 28^{\circ} \mathrm{C} \text { WBGT } \\
\text { - } 29.5^{\circ} \mathrm{C} \text { dry-bulb temp } \\
\text { - } 0.3 \text { to } 0.5 \mathrm{~m}^{-1} \mathrm{~s}^{-1} \text { air velocity) }\end{array}$ & $\begin{array}{ll}\text { - } & \text { Oral temp }<37.6^{\circ} \mathrm{C} \\
\text { - } & \text { Rectal temp }<38.9^{\circ} \mathrm{C} \\
\text { - } & \mathrm{HR}<160 \mathrm{bpm}\end{array}$ \\
\hline & \multirow[t]{2}{*}{$\begin{array}{l}\text { Post-shift dehydration } \\
\text { test* }\end{array}$} & \multirow[t]{2}{*}{ Incumbents } & $\begin{array}{l}\text { Measurement of urinary specific } \\
\text { gravity (USG) }\end{array}$ & - $\mathrm{USG} \leq 1.030$ \\
\hline & & & $\begin{array}{l}\text { Measurement of urinary chloride } \\
\text { (Fantus test) }\end{array}$ & $\begin{array}{l}\text { - Sodium excretion rate } \\
\leq 50 \mathrm{mmol} / 24 \mathrm{~h}\end{array}$ \\
\hline Military & $\begin{array}{l}\text { Heat Tolerance Test } \\
(\mathrm{HTT})^{*}\end{array}$ & $\begin{array}{l}\text { Incumbents with } \\
\text { heat illness }\end{array}$ & $\begin{array}{l}\text { Treadmill-walking exercise in heat } \\
\text { chamber } \\
\text { - } 120 \text {-min at } 5 \mathrm{~km} \cdot \mathrm{hr}^{-1} \text { and } 2 \% \\
\text { incline } \\
\text { - } 40^{\circ} \mathrm{C} \text { dry-bulb temp } \\
\text { - } 40 \% \mathrm{RH}\end{array}$ & $\begin{array}{ll}\text { - } & \text { Rectal temp }<38.6^{\circ} \mathrm{C} \\
\text { - } & \text { HR }<160 \mathrm{bpm} \\
\text { - } & \text { Plateau of rectal temp } \\
& \text { and } / 0 \mathrm{r} \text { HR }\end{array}$ \\
\hline
\end{tabular}




\begin{tabular}{|c|c|c|c|c|}
\hline Firefighting & Trondheim test* & Applicants & $\begin{array}{l}\text { (Part } 2 \text { of the test) } \\
\text { Carry concrete blocks up and down } \\
\text { the stairs in heat chamber } \\
\begin{array}{r}\text { - } 10 \text { concrete blocks ( } 18 \mathrm{~kg} \\
\text { each) } \\
\text { - } 7 \text { steps (each } 18 \mathrm{~cm} \text { high) } \\
\text { each way } \\
\text { - } 120 \text { to } 140^{\circ} \mathrm{C} \text { ambient temp }\end{array}\end{array}$ & $\begin{array}{l}\text { - Complete entire test in } \\
\leq 19 \mathrm{~min}\end{array}$ \\
\hline \multirow[t]{2}{*}{ HAZMAT } & $\begin{array}{l}\text { Pre-entry medical } \\
\text { examination* }\end{array}$ & Incumbents & $\begin{array}{l}\text { Medical screening performed prior } \\
\text { to undertaking work at the } \\
\text { fire/HAZMAT scene }\end{array}$ & $\begin{array}{ll}\text { - } & \text { Core temp }<37.2^{\circ} \mathrm{C} \\
\text { - } & \text { Pulse } \leq 100 \mathrm{bpm} \\
\text { - } & \text { Blood pressure between } \\
& 90 / 60 \text { and } 150 / 90\end{array}$ \\
\hline & Hot Bruce test ${ }^{\dagger}$ & Applicants & $\begin{array}{l}\text { Maximal treadmill exercise (i.e. } \\
\text { Bruce protocol) while dressed in } \\
\text { impermeable protective suit }\end{array}$ & - To be established \\
\hline
\end{tabular}

*Tests that are currently in use

${ }^{\dagger}$ Tests that are yet to be implemented 
Table 2. Controls for reducing cold stress. Summarized from Keim et al., Ann. Agric. Environ. Med. 2002; 9:1-15.

\begin{tabular}{|c|c|c|}
\hline Engineering controls & Administrative controls & Personal protection controls \\
\hline $\begin{array}{l}\text { General and hand } \\
\text { warming }\end{array}$ & Work-rest cycles & Appropriate clothing \\
\hline $\begin{array}{l}\text { Reducing conductive heat } \\
\text { loss }\end{array}$ & Work schedule changes & Hand protection and rewarming \\
\hline $\begin{array}{l}\text { Minimizing air } \\
\text { movement }\end{array}$ & Additional workers & Attention to exposed body parts \\
\hline \multirow[t]{4}{*}{ Use of warming shelters. } & $\begin{array}{c}\text { Observation of workers - } \\
\text { buddy system }\end{array}$ & Avoid getting wet \\
\hline & $\begin{array}{l}\text { Avoid long sedentary } \\
\text { periods }\end{array}$ & \\
\hline & $\begin{array}{l}\text { Acclimatization for new } \\
\text { workers }\end{array}$ & \\
\hline & Medical surveillance & \\
\hline
\end{tabular}




\section{List of Figures}

Figure 1. Monthly occupationally-related emergency department encounters and normalized for full-time employee hours in southwest Ontario, Canada 2004-2010. Absolute visits increase dramatically $>22^{\circ} \mathrm{C}$, but risks remain very low due to overall high rates of exposure. In contrast, $>28^{\circ} \mathrm{C}$ the rates of exposure falls sharply, resulting in a $>25$-fold increase in risks of occupational morbidity. FTE = full-time employee hours. Created from data in Fortune et al., Environ. Res. 2014; 132:449-456.

Figure 2. Summary of recommended wet bulb globe temperature (WBGT) threshold values for low, moderate, high, and very high risk of heat-related illnesses from different international organizations.

Figure 3. Occupational cold exposure, mediating factors, and effects on performance and health. Created from information in Makinen \& Rossi 2009.

Figure 4. Correlation between muscle temperature and jump height of the drop jump test. In a cold environment, this translates to greater relative force required to complete a task, or else reduced work capacity or tolerance. Each point represents eight subjects except at $1(n=7)$ and 2 $(\mathrm{n}=3)$. Reproduced from Racinais and Oksa, Scand. J. Med. Sports Sci. 2010; 20:1-18 with permission. 


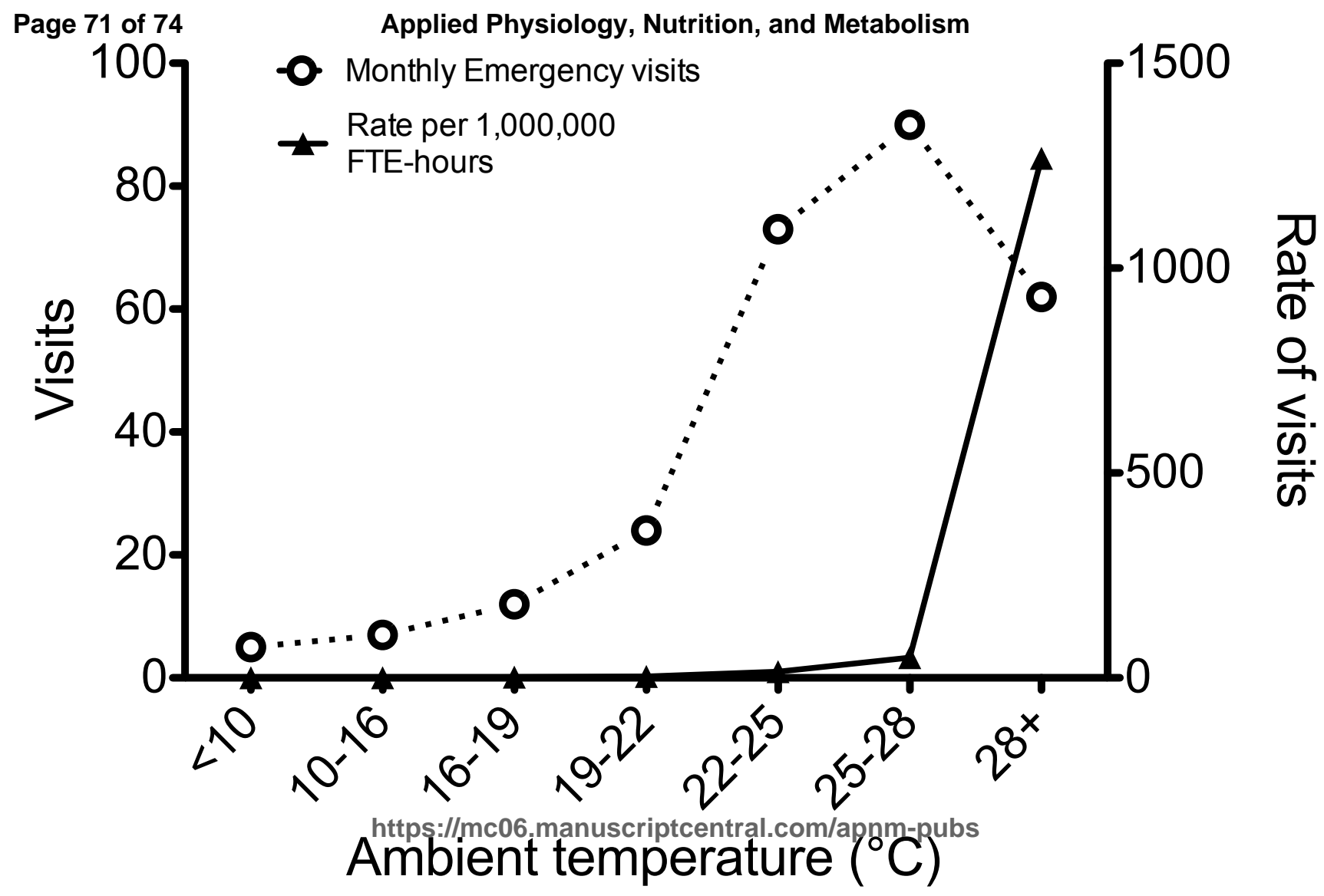




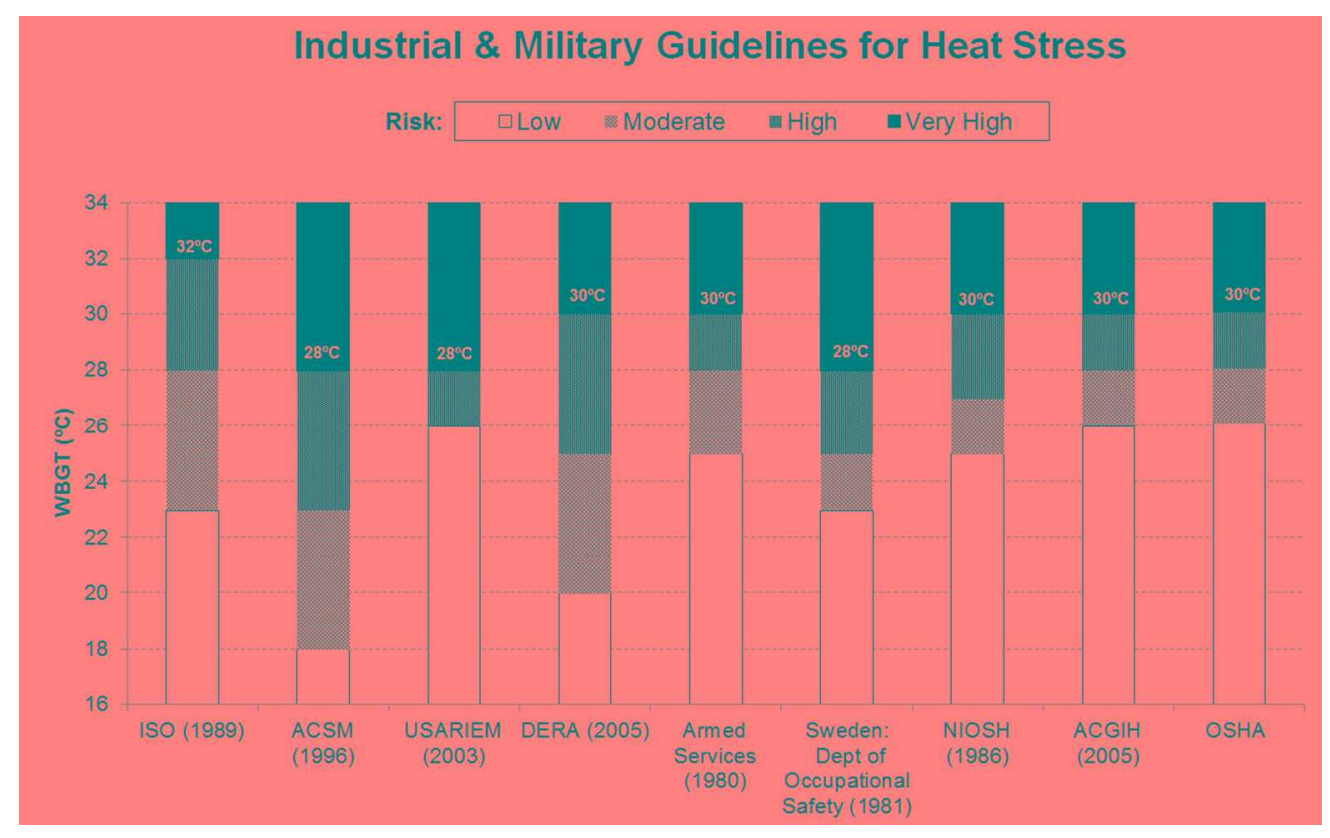

$108 \times 67 \mathrm{~mm}(300 \times 300$ DPI $)$ 


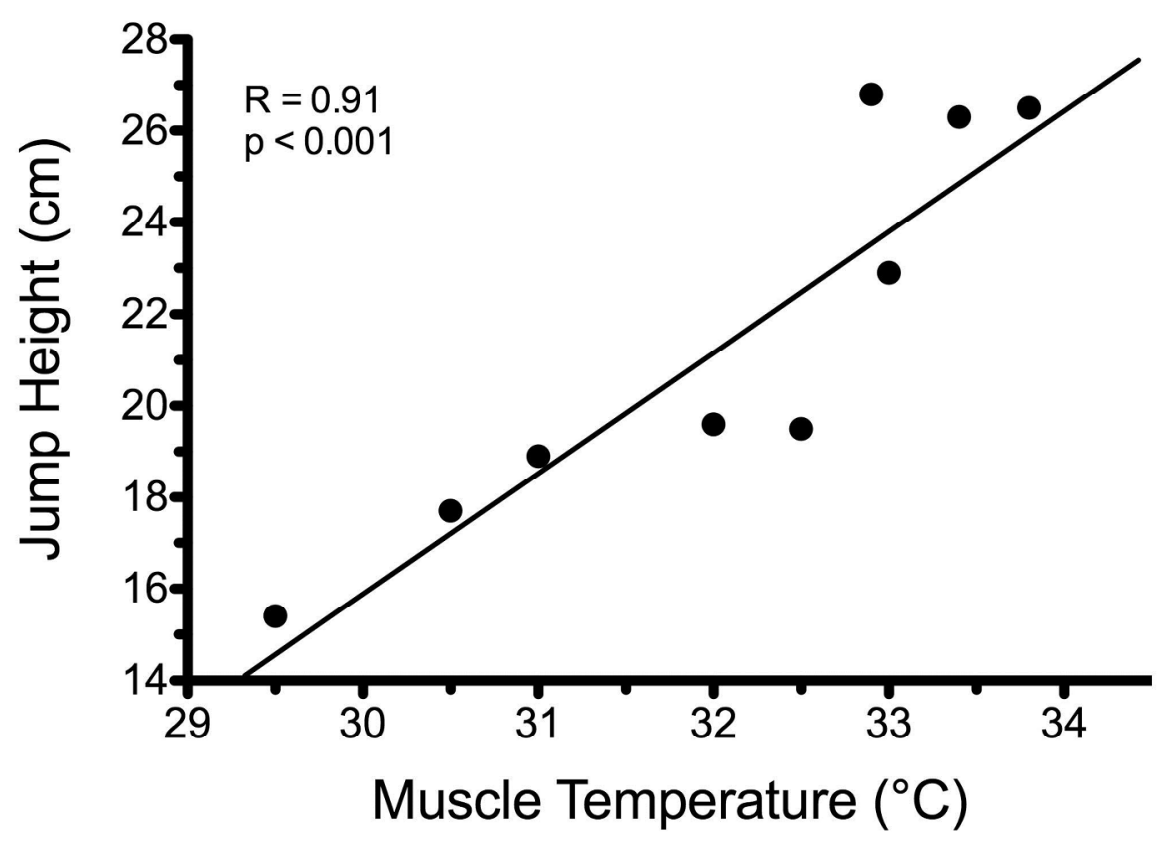

$193 \times 133 \mathrm{~mm}(300 \times 300 \mathrm{DPI})$ 